I NTER NATIONAL MONETARY FUND

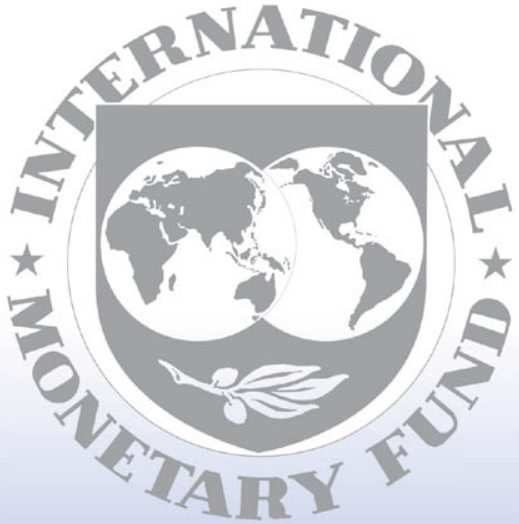

Staff

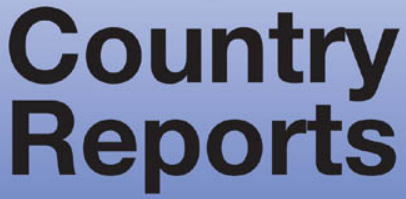




\section{Algeria: Selected Issues Paper}

This selected issues paper on Algeria was prepared by a staff team of the International Monetary Fund as background documentation for the periodic consultation with the member country. It is based on the information available at the time it was completed on December 27, 2011. The views expressed in this document are those of the staff team and do not necessarily reflect the views of the government of Algeria or the Executive Board of the IMF.

The policy of publication of staff reports and other documents by the IMF allows for the deletion of market-sensitive information.

Copies of this report are available to the public from

International Monetary Fund • Publication Services

$70019^{\text {th }}$ Street, N.W. • Washington, D.C. 20431

Telephone: (202) 623-7430 • Telefax: (202) 623-7201

E-mail: publications@imf.org Internet: http://www.imf.org

\section{International Monetary Fund \\ Washington, D.C.}


This page intentionally left blank

CInternational Monetary Fund. Not for Redistribution 


\section{INTERNATIONAL MONETARY FUND}

\section{ALGERIA}

\section{Selected Issues}

Prepared by José Gijón, Davide Furceri, and Ernesto Crivelli (all MCD)

Approved by the Middle East and Central Asia Department

December 27, 2011

Contents

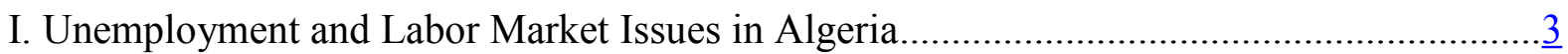

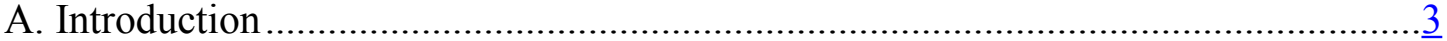

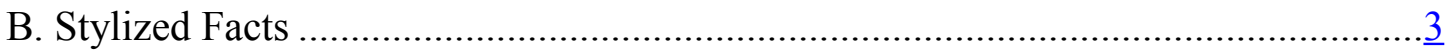

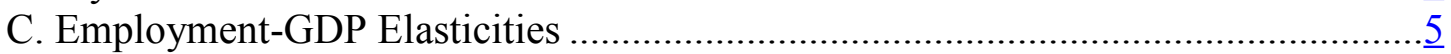

D. Labor Market Flexibility and Unemployment ……….......................................

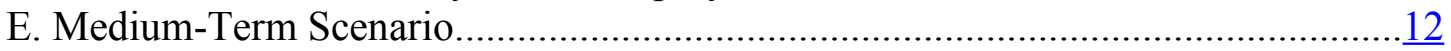

F. Conclusions and Policy Implications............................................................14

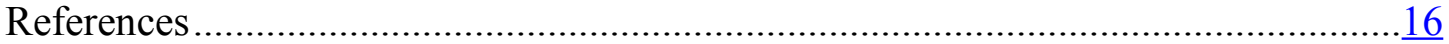

Tables

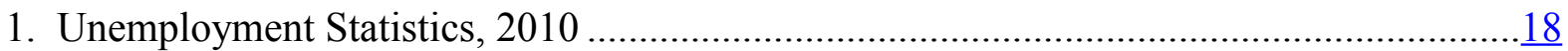

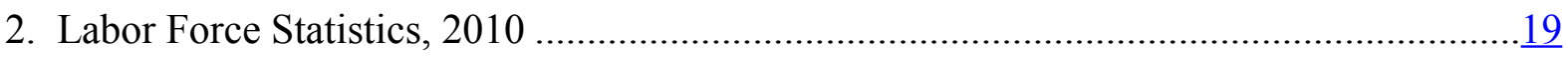

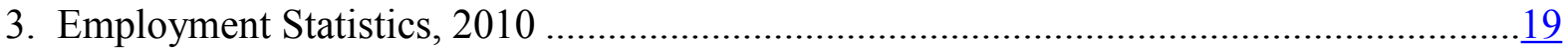

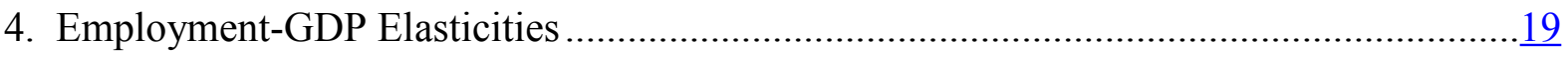

5. Unemployment and Labor Market Flexibility-Static Regression (OLS) ...........................20

6. Unemployment and Labor Market Flexibility-Dynamic Regression (GMM) .....................21

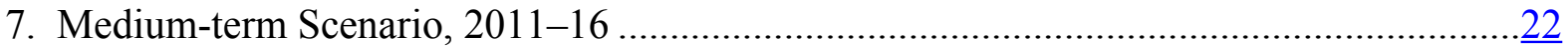

Figures

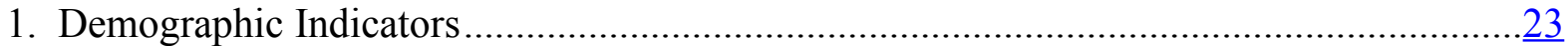

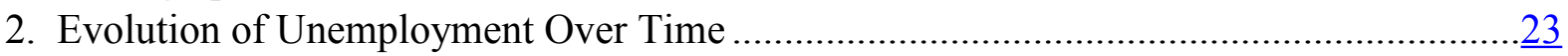

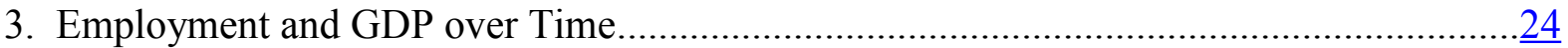

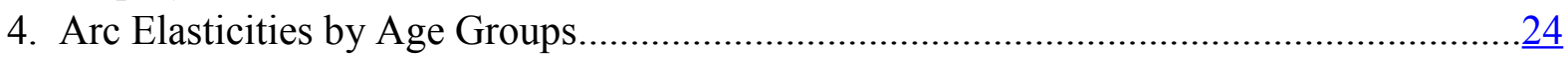

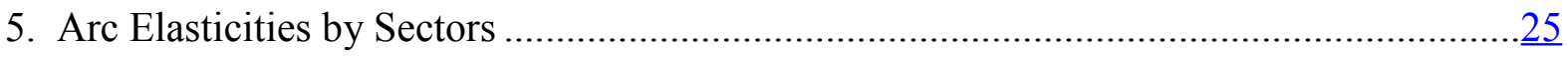

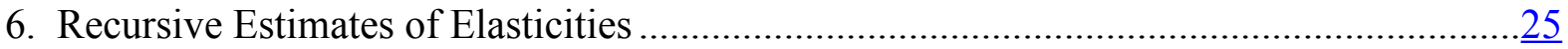

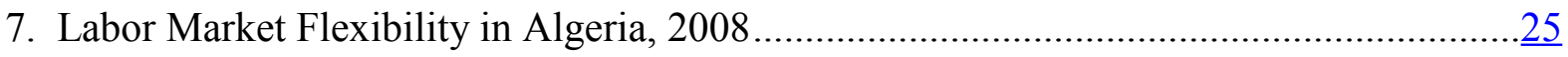

8. Evolution of Labor Market Flexibility over Time ..........................................................

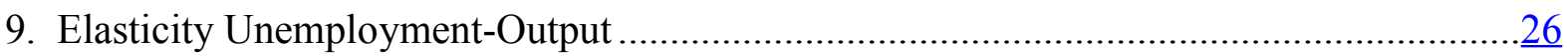

10. Labor Market Flexibility and Medium-term Unemployment .........................................27 
II. Optimal International Reserves in Algeria .......................................................................

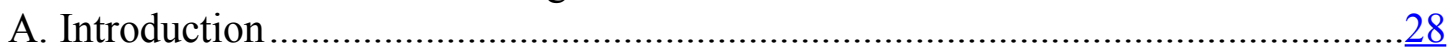

B. Traditional Measures for Assessing Reserve Adequacy ……………………….....

C. Standard Econometric Analysis ...............................................................................34

D. Adjusting Reserves to the Algerian Policy Framework: the Permanent Income

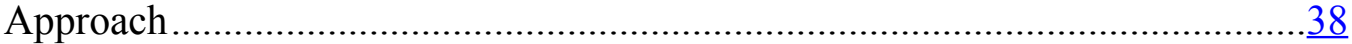

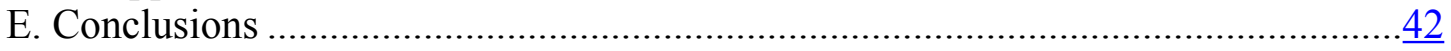

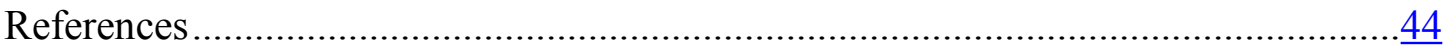

Tables

1. Reserve Adequacy Rations for Selected Emerging Economies …………........................

2. Algeria's WK Composite Reserve Adequacy Indicator ...................................................

3. Algeria's WK Composite Reserve Adequacy Indicator with Three Months Import

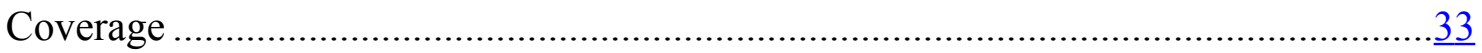

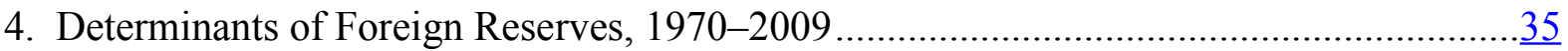

5. Algeria's Excess Reserves Under the Permanent Income Scenario and WK's Composites

Figures

1. Algeria's International Reserves and International Oil Price ...........................................28

2. WK Index Assuming 20 Percent and 100 Percent Chances of Capital Flight Risk .............32

3. Algeria's International Reserve, Actual Versus Fitted Values ..........................................

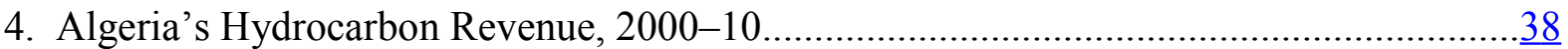

5. Reserve Accumulation Forecast Under the Permanent Income Framework, 2003-43, in 2003 Constant US\$ Billion

\section{Annexes}

I. Traditional Measures for Reserve Adequacy $\underline{46}$

II. Estimation of Reserve Adequacy for Oil Exporters with Sovereign Wealth Funds ...........49

III. Determinants of Foreign Reserves 


\section{UnEMPLOYMENT AND LABOR MARKET ISSUES IN AlgERIA}

\section{A. Introduction}

1. Despite several years of sustained growth, the unemployment rate in Algeria remains high compared to other emerging economies. In addition, while growth performance in the last ten years was accompanied by a significant reduction in the overall unemployment rate, youth unemployment has proven more difficult to tackle. Given demographic trends and expected future increases in the labor force among the youth, youth unemployment is likely to remain high over the medium term.

2. This paper analyzes unemployment and labor market developments in Algeria and assesses the factors that may hamper employment creation. In doing so, it estimates employment-GDP elasticities for Algeria's main sectors and different age groups and it assesses the effect of improvements in Algeria' labor market flexibility on unemployment outcomes.

3. The results of the paper suggest that the relative low elasticities are the main factors behind the still high level of youth unemployment. The analysis of the paper also suggests that one important factor behind the low responsiveness of employment and unemployment to GDP growth in Algeria is the relative rigid labor market. In particular, the results on the relation between labor market institutions and unemployment show that improvement in labor market conditions in Algeria could have a significant effect in reducing unemployment both in the short and medium term.

4. The paper also presents some stylized scenarios on the future evolution of unemployment and shows that in absence of reforms aimed at improving the responsiveness of labor market conditions to changes in economic activity, unemployment is likely to remain high over the medium term.

5. The paper is organized as follows. The next section presents key descriptive statistics on Algeria's labor market. Section III estimates GDP-employment elasticities for Algeria's main sectors and for different age groups and shows how they have evolved over time. Section IV presents Algeria-specific estimates of the impact of labor market flexibility on unemployment outcomes. Section V presents some stylized medium-term scenarios for the evolution of unemployment and employment over the medium term. Section VI concludes with the main policy implications.

\section{B. Stylized Facts}

6. The overall unemployment rate in Algeria has declined considerably over the last decade falling from 30 percent in 2000 to only 10 percent in 2010 (Table 1). Demographic factors have played an important role in affecting the dynamic of unemployment rates. Over the last three decades Algeria has undergone a rapid demographic transition to low fertility. 
Fertility rates have continuously decreased from 5.8 percent in 1985 to 2.4 percent in 2007. As a result, population growth has declined from 3.1 percent to 1.5 percent over the same period (Figure 1).

7. Participation rates have also steadily declined during the last decade generating fewer entrants into the labor market and contributing to substantially lower unemployment rates. ${ }^{1}$ The additional demand for job, as expressed by labor force growth, has declined from an average of 4.2 percent over the period 1991-2000 to 2 percent over 2001-10. In contrast, employment growth has increased over the same period from an average of 2.9 percent in 1991-2000 to 4.7 percent in 2001-10, leading to lower unemployment.

8. However, despite the large gains in the overall rate of unemployment observed during the last decade, unemployment has not decreased with the same speed for several segments of the population, particularly for the youth. As a result, the ratio of youth unemployment to overall unemployment has steadily increased over the recent period (Figure 2).

9. In addition to youth unemployment (which is currently at 21.5 percent (Table 1)), high unemployment rates are recorded mainly for women and people with higher level of education (respectively, 19 and 20 percent - Table 1). While the high level of female unemployment may be largely driven by social factors, labor market imperfections play an important role in high unemployment rates among young graduates. First, as described more in detail in the rest of the paper, Algeria's labor market is relatively rigid, and therefore tends to favor insider versus outsider workers. Second, the high level of unemployment among young graduates is also the result of mismatches between labor market demand and supply: on the one hand, the economy has not been able to create sufficiently high skilled jobs; on the other hand, there seems to be an unbalanced distribution of Algerian students in favor of fields (such as humanities, social sciences, law and education) that generate an undersupply of the skills most needed by the private sector (Table 1).

10. These labor market imperfections also play an important role in explaining the very long length of unemployment spells in the Algeria's labor market - almost 50 percent of unemployed have been seeking a job for more than two years (Table 1). In fact, relative rigid labor markets and labor-market mismatches tend to reduce job turnover and increase the incidence of long-term unemployment. In addition, the low turnover associated with a rigid labor market may also reduce the effectiveness of active labor market policies aiming at integrating outsider workers in the labor market.

\footnotetext{
${ }^{1}$ See Table 2 for a breakdown of labor force participation among the different age/gender groups.
} 


\section{Employment-GDP Elasticities}

11. A valuable indicator for understanding the evolution of labor market outcomes is the elasticity of employment with respect to output. This indicator provides information on the employment intensity of growth and gives indication on how employment and GDP growth are correlated. Figure 3 displays the evolution of the growth rate of the non hydrocarbon sector $^{2}$ and of employment. Looking at the figure, despite the fact that the two series have not considerably co-moved over time, the employment intensity of growth has been in general relative high over the entire period. ${ }^{3}$ This has been reflected in a relatively high arc elasticity (defined as the ratio of employment growth to non hydrocarbon GDP growth) which over the period has been on average equal to 0.64 .

12. However, the computation of the arc elasticity for overall employment may mask significant differences across different age groups. In fact, while the employment intensity of growth has been on average relatively high, the arc elasticity for young has been considerably low. Differentiating between the age group 15-24 and the group aged 24+, Figure 4 shows that the arc elasticity for young people over the recent 5 years has been half of the average arc elasticity for total employment and about one third of the arc elasticity of the age group $24+$. Among the different sectors of economic activity, while services sectors absorb the largest part of new entrants (Table 3), the sector being characterized by the highest employment intensity of growth is industry (Figure 5).

13. However, as shown in Figures 3-5, the estimates of arc elasticities have to be interpreted with some caution since they tend to be very volatile and extremely sensitive to abrupt changes in employment and GDP. In order to address this issue, a measure of elasticity is estimated using a dynamic time-series specification of employment and non hydrocarbon GDP:

$\ln \left(E_{t}\right)=\alpha+\rho \ln \left(E_{t-1}\right)+\beta \ln \left(Y_{t}\right)+\omega_{t}$

where $E$ is the level of employment, $Y$ the non hydrocarbon GDP, $\rho$ indicates the persistence of employment and $\beta$ is the short-term (i.e. contemporaneous) elasticity. While the elasticities obtained using equation (1) still have to be interpreted in terms of correlation between output and employment rather than causality, they are considerably less volatile than the arc elasticity.

\footnotetext{
${ }^{2}$ The reason of focusing only on the nonhydrocarbon sector is that the hydrocarbon sector employs less than 5 percent of total employment even though it represents about 35 percent of total GDP. In addition, employment in the hydrocarbon sector is usually not very much correlated with changes in production.

${ }^{3}$ The correlation between employment growth and nonhydrocarbon GDP growth is about 0.1 .
} 
14. In addition, the use of equation (1) allows to identify the responsiveness of employment to output over different time horizons. In particular, for each period $k$, the $k$ ahead cumulative response of employment to output can be computed as: $\sum_{i=0}^{k} \beta \rho^{i}$.

15. Equation (1) is estimated using OLS over the period 1993-2010. The problem of the relative low number of degrees of freedom is mitigated by the fact that equation (1) is a cointegration relationship ${ }^{4}$ and therefore the OLS estimates are "super-consistent," in the sense that they converge more quickly than OLS estimates based on I(0) variables (Stock, 1987). The results from OLS estimates yield:

$$
\ln \left(E_{t}\right)=-2.882+0.442 \ln \left(E_{t-1}\right)+0.497 \ln \left(Y_{t}\right)
$$

where $t$-statics are in parenthesis, and the associated $R^{2}$ is 0.97 . Using the estimated parameters reported above, the $k$-ahead cumulative response of employment to output is computed over different time horizons (Table 4). Given that the persistence of employment is less than one, which also ensures the stability of the empirical specification, the cumulative response of employment increases over time and is bounded. In particular, while the shortterm elasticity is about 0.5 , the long-term elasticity (for $k \rightarrow \infty$ ) is about 0.9 .

16. While the elasticities computed using equation (1) help to smooth the correlation between output and employment, it could still be the case that they can evolve over time. To assess the evolution of the estimated employment-output elasticity over time, equation (1) was recursively estimated over the following periods: 1993-2000, 1993-2001, and 19932010. The results obtained for the short-run elasticity are displayed in Figure 6 and suggest that the employment intensity of growth has significantly declined over the most recent period. ${ }^{5}$ This reduction in the employment intensity of growth may suggest that in order to continue to reduce unemployment over the medium term, particularly among the segments of the population with highest rates, continuously larger gains in growth and/or changes in the factors underpinning employment elasticities will be needed.

17. Previous theoretical and empirical evidence has identified a possible set of determinants of the employment-output elasticities, including (i) economic openness and export orientation, (ii) product market regulation and competitiveness, (iii) the size of public sector, and (iv) the rigidity of the labor market. While there are few empirical studies that assess the roles of these variables simultaneously, there is tentative evidence suggesting that lower economic openness, large public sectors and more rigid labor and product markets are

\footnotetext{
${ }^{4}$ The presence of co-integration has been tested using unit root tests on the residuals based on the Augmented Dickey-Fuller and Phillips-Perron tests.

${ }^{5}$ The decline in the employment intensity of growth is reflected in the increase of labor productivity growth.
} 
associated with lower elasticities and therefore higher levels of unemployment. ${ }^{6}$ The next section will analyze in detail the role of labor market flexibility in Algeria.

\section{Labor Market Flexibility and Unemployment}

18. Economic theory and previous empirical studies have identified a number of policy and institutional determinants of unemployment, including unemployment benefits, tax wedges, the structure of collective bargaining, employment protection legislation, minimum wages and hiring costs. Overall, previous empirical evidence has in general concluded that more rigid labor market institutions may obstruct job creation and tend to be associated with higher levels of unemployment. ${ }^{7}$

19. While most of the empirical research has focused on single indicators of labor market institutions, recent studies (e.g., Feldman 2009, and Bernal-Verdugo et al. 2011a, 2001b) have also focused on composite indicators of labor market flexibility. The reason to consider a composite indicator is the inherently complex nature of labor market regulation and the evidence that improvement in labor market efficiency are likely to require reforms in more than one area of the labor market (Bassanini and Duval, 2009).

20. The empirical evidence provided in recent studies analyzing the effect of composite indicators of labor market flexibility has in general confirmed that more rigid labor markets are associated with higher level of unemployment. However, while these studies have provided average estimates for large sets of countries, it is likely that the effect of labor market flexibility on unemployment outcomes depends on countries' structural and macroeconomic specific characteristics. The aim of this section is to analyze the effect of labor market flexibility on unemployment, including for Algeria.

\section{Indicator of labor market flexibility}

21. The dataset used in the empirical analysis consists of a panel of annual data for 183 countries spanning from 1980 to 2008. Data for labor market flexibility are taken from the Fraser Institute's Economic Freedom of the World (EFW) database. The database

\footnotetext{
${ }^{6}$ For exemple, Bruno et al. (2001) find that measures of globalization and external balance are correlated with employment intensity. Mourre (2004) and Dopke (2001) find that that employment protection and labor market rigidity have a negative impact on employment intensity. Bassanini and Duval $(2006,2009)$ find that product market regulations are correlated with the persistence and the responsiveness of unemployment to GDP shocks. Feldman (2006) finds that the size of government affects the level of unemployment.

${ }^{7}$ For example, Nickel (1998), Elmeskov et al. (1998) and Nunziata (2002) find robust evidence that the level and the duration of unemployment benefits have positive effects on unemployment. Belot and Van Ours (2004) and Nickell (1997) find that high labor taxes tend to increase unemployment rates. Botero et al. (2004) find that more rigid employment laws are associated with high unemployment, especially for the young. See Bassanini and Duval (2006) for a detailed review.
} 
provides a composite measure of labor maker flexibility based on six policy areas:

(i) Minimum wage, (ii) Hiring and Firing regulation, (iii) Centralized collective wage bargaining, (iv) Mandated cost of hiring, (v) Mandated cost of work dismissal, and (vi) Conscription. ${ }^{8}$ The composite indicator is standardized on a 0-10 range, with higher value of the indicator representing a more flexible labor market.

22. Figure 7 shows the indicator of labor market flexibility for Algeria and compares it with those of other emerging countries. This indicator points to Algeria's labor market being overall rigid in absolute terms (scoring 5 out of 10), and less flexible than in other MENA and emerging countries. Moreover, looking at the evolution of the indicator over time, it seems that labor market rigidity has increased over the most recent period for which data for the indicator are available (Figure 8).

\section{Empirical methodology and results}

23. In this section, we discuss the empirical methodology used to analyze the relationship between labor market flexibility and unemployment outcomes in Algeria, and we present the results of the econometric estimations under alternative model specifications.

24. We divide our empirical analysis in two parts. First, we estimate a static model specification to test for the hypothesis that the quality of labor market regulations has a first order effect on unemployment outcomes in Algeria. Second, we estimate a dynamic model specification to test whether labor market flexibility in Algeria affects the change in unemployment over time. Using a sample of 140 countries spanning the period 1980-2008, our findings indicate that, after controlling for other macroeconomic and demographic variables, increases in the quality of labor market regulations and institutions have a statistically significant negative impact both on the level and on the change of unemployment outcomes.

\footnotetext{
${ }^{8}$ In detail: (i) Hiring regulations and minimum wage are based on the World Bank's Difficulty of Hiring Index (this measure gives lower ratings to countries with a higher difficulty of hiring); (ii) Hiring and Firing regulations based on the World Economic Forum's Global Competitiveness Report (this measure gives a lower rating to countries in which the free hiring and firing of workers is impeded by regulation); (iii) Centralized collective bargaining assigns ratings based on the centralization of the wage bargaining process, which are higher for countries with a more decentralized bargaining process; (iv) Mandated cost of hiring is based on the World Bank's Doing Business data on the cost of all social security and payroll taxes and the cost of other mandated benefits including those for retirement, sickness, health care, maternity leave, family allowance, and paid vacations and holidays associated with hiring an employee; (v) the index of Mandated cost of worker dismissal rates countries based on the cost of the requirements for advance notice, severance payments, and penalties due when dismissing a redundant worker; (vi) the index of Conscription rates countries based on the use and duration of military conscription, with the highest rating given to countries without military conscription.
} 


\section{Static relationship between unemployment and labor market institutions}

25. In order to assess the relationship between labor market flexibility and the level of unemployment in Algeria we employ a standard static reduced-form specification in which unemployment is regressed against our measure of labor market flexibility, the interaction term between labor market flexibility and a dummy variable for Algeria, and a set of macroeconomic and demographic variables as controls:

$U_{i t}=\alpha_{i}+\beta L_{i t}+\delta L_{i t} D_{t}+\gamma^{\prime} \boldsymbol{X}_{i t}+\varepsilon_{i t}$

where $U_{i t}$ is the unemployment rate for country $i$ at time $t, L_{i t}$ is the composite indicator of labor market flexibility; $D_{t}$ a dummy variable that takes value equal to 1 for Algeria and zero otherwise; $\alpha_{i}$ represents country dummies that capture unobserved country-specific determinants of unemployment, $\boldsymbol{X}_{i, t}$ is a vector of control variables, ${ }^{9}$ including a measure of output gap to control for business cycle fluctuations (proxied by the difference of the GDP growth rate from a 5-year moving average), the size of government (proxied by the log of the ratio of government consumption to GDP), the degree of trade openness (measured as the log of the ratio of total exports and imports to GDP), the rate of urbanization, population density, a crisis dummy which takes value equal to 1 for the occurrence of a financial (banking, debt and currency) crisis and zero otherwise, and a common time trend.

26. In equation (2), the impact of labor market flexibility on unemployment in Algeria is given by $\beta+\delta$. The reason to use a panel approach with country-specific slopes instead of relying on a time-series regression is due to the fact that data for labor market flexibility for Algeria are available only for the period 2000-2008, and therefore the number of observations is not sufficient to perform a meaningful time-series exercise.

27. The main results regarding the relationship between unemployment and labor market institutions are shown in Table 5, which displays the estimates for the static specifications of the econometric model. First and foremost, in all specifications, improvements in the quality of labor market regulations that allow for a higher degree of flexibility have a statistically significant negative effect on unemployment. Interestingly, the effect is larger in Algeria than for the average of the countries in the sample. In particular, the results suggest that in Algeria an increase in the composite labor market index of one standard deviation would decrease the unemployment rate by about 1 percentage point. The significance and the magnitude of the

\footnotetext{
${ }^{9}$ The sources of the data for the other variables used in the empirical analysis are the IMF's World Economic Outlook (WEO), the World Bank's World Development Indicators (WDI), and the Penn World Table version 7.0 by Heston et al. (2011).
} 
effect are extremely robust across all specifications. In addition, the results are also robust when the sample is restricted to non-OECD countries. ${ }^{10}$

28. Among the control variables, apart from our measure of output gap, we find that government size has a positive and statistically significant effect on changes in unemployment (column II). This result is consistent with previous empirical evidence suggesting that countries characterized by a larger government size and a larger share of public employment tend to have higher unemployment rates (e.g., Feldman, 2006). ${ }^{11}$

\section{Dynamic relationship between unemployment and labor market institutions}

29. In order to assess the relationship between labor market flexibility and changes in unemployment we use a dynamic reduced-form specification in which changes in unemployment are regressed against our measure of labor market flexibility, the interaction term between labor market flexibility and the dummy variable for Algeria, and the set of macroeconomic and demographic variables described in the previous section:

$\Delta U_{i t}=\alpha_{i}+\rho U_{i t-1}+\beta L_{i t}+\delta L_{i t} D_{t}+\gamma^{\prime} \boldsymbol{X}_{i t}+\varepsilon_{i t}$

30. To address endogeneity due to the presence of the lagged level of unemployment among the regressors and to reverse causality from changes in unemployment to labor market flexibility, equation 3 has been estimated using the two-step GMM-system estimator. ${ }^{12}$

31. Table 6 displays the estimates for different specifications. Looking at the table, it is evident that improvements in the quality of labor market regulations that allow for a higher degree of flexibility have a statistically significant effect, inducing a decline in unemployment. As for the static specification, the results suggest that the effect is larger in Algeria than for the average of the countries in the sample, with an increase in the composite labor market index of one standard deviation decreasing unemployment rate by about 0.9 1.2 percentage point. In particular, the results for our baseline specification (first column),

\footnotetext{
${ }^{10}$ The results are available from the author upon request.

${ }^{11}$ There are several reasons for which government size can affect unemployment and the elasticity between employment and GDP. First, a large government sector tends to crowd out private investment and reduce growth over the medium-term (Afonso and Furceri, 2009). Second, as the private sector is relatively small, its ability to absorb new labor force entrants is reduced. Third, a large government sector often involves higher taxes which can have depressive effects on aggregate demand and on the labor market (Daveri and Tabellini, 2000). Overall, previous empirical evidence has confirmed the hypothesis that a higher government size is associated with higher unemployment rates (e.g., Feldman, 2006).

${ }^{12}$ The two-step GMM-system estimates (with Windmeijer standard errors) are computed using the xtabond2 Stata command developed by Roodman (2009a). All explanatory variables are considered as endogenous (instrumented using up to 2 lags). The significance of the results is robust to different choices of instruments and predetermined variables.
} 
which includes the lagged level of unemployment and our measure of output gap as a control, suggest that a one standard deviation increase in the labor market index is associated with a decrease in the annual change in unemployment of about 1.1 percentage points. In addition, the fact that the term of the lag of unemployment is statistically significant and higher than $1^{13}$ implies that improvement in labor market flexibility in Algeria will be able to reduce unemployment rate also over the medium term.

32. Among the control variables, apart from the lag of unemployment, we find that financial crises have a positive and statistically significant effect on changes in unemployment (column VI). This result is consistent with previous empirical evidence suggesting that financial crises lead to a significant and persistent increase in unemployment (e.g., Bernal-Verdugo et al. 2011a).

33. Consistency of the two-step GMM estimates has been checked by using the Hansen and the Arellano-Bond tests. The Hansen J-test of over-identifying restrictions, which tests the overall validity of the instruments by analyzing the sample analog of the moment conditions used in the estimation process, cannot reject the null hypothesis that the full set of orthogonality conditions are valid (across the different specifications the p-value ranges from 0.25 to 0.56 ). The Arellano-Bond test for autocorrelation cannot reject the null hypothesis of no second-order serial correlation in the first-differenced error terms (across the different specifications the $\mathrm{p}$-value ranges from 0.47 to 0.54 ).

34. In order to assess whether the results are robust across different country groups characterized by different levels of economic development, equation (2) has been estimated excluding from the estimation sample the OECD countries. As pointed out by Roodman (2009b), a problem with applying GMM-system estimator is that it may generate too many instruments which may reduce the efficiency of the two-step estimator and weaken the Hansen test of the instrument's joint validity. This could be an important issue when the number of countries is relatively small compared to the number of instruments, as it is the case when OECD countries are excluded from the estimation sample. To address this issue, and following Roodman's suggestion, we have applied the GMM-system estimator based on a collapsed number of instruments. The results obtained with this approach suggest that the effect of the quality of labor market institutions is statistically significant, and the effect is still larger for Algeria than for the average of the countries in the sample. ${ }^{14}$

\footnotetext{
${ }^{13}$ This implies that the autocorrelation coefficient of the level of unemployment is between 0 and 1 .

${ }^{14}$ The results are available from the author upon request.
} 


\section{Unemployment-output elasticity and labor market flexibility}

35. A channel through which labor market institutions affect the level of unemployment is the response and the persistence of labor market conditions to observed and unobserved shocks (e.g., Blanchard and Wolfers, 2000; Bassanini and Duval, 2009). Overall, previous evidence has in general pointed out that the resilience of unemployment to shocks is larger in countries with more flexible labor market.

36. In order to test this finding and assess the response of unemployment to GDP for Algeria, a two step approach has been carried out. First, unemployment and youth unemployment elasticities have been computed as described in equation (1). The results suggest that the overall rate of unemployment reacts more strongly than the rate of youth unemployment to changes in GDP. Second, the estimated elasticities for all countries in the sample are regressed against the composite indicator of labor market flexibility.

37. Figure 9 plots the relation between unemployment-output (Panel A) and youth unemployment-output (Panel B) elasticities and labor market flexibility, and confirms previous findings suggesting that gains in growth are likely to be translated into larger reductions in total and youth unemployment the more flexible is the labor market. In addition, given that in Algeria youth unemployment has been less responsive to changes in economic activity, improvements in labor market flexibility will tend to have a higher effect on youth unemployment.

\section{E. Medium-Term Scenario}

38. This section presents stylized scenarios on the evolution of unemployment over the medium term based on two different alternative methodologies. In the first part of the analysis, the medium-term scenarios for unemployment are constructed using ILO (2011) estimates of the economically active population based on demographic projections and alternative measures of employment-GDP elasticities. In the second part of the analysis, the evolution of unemployment over the medium term is projected using the estimated elasticities between the unemployment rate and GDP.

39. From a technical point of view, the main advantage of using the first methodology is to take into consideration demographic trends that affect the medium-term evolution of the economically active population. However, since projections for changes in labor force participations are mostly based on demographic trends, a limitation of this approach is that it assumes that changes in economic activity would not have an impact in the decision of entering and exiting the labor force. In contrast, while the second methodology does not suffer from this problem, since the response of unemployment to economic activity is directly estimated, it does not take into account demographic trends which can affect participation rates over the medium term. 
40. Despite these differences, the results obtained with both analyses suggest that in absence of reforms aimed at improving the responsiveness of labor market conditions to changes in economic activity, unemployment is likely to remain high over the medium term.

\section{ILO projections and employment-GDP elasticities}

41. Table 7 presents alternative scenarios of the evolution of unemployment over the medium term under different growth and employment-GDP elasticities, and using the ILO estimates of net labor force entrance over the period 2011-16.

42. The baseline scenario shows that assuming employment-GDP elasticity equal to the one estimated in the first column of Table 4, an average growth rate for non hydrocarbon GDP of 5 percent would lead to a reduction in unemployment of about 1.3 percentage points over the medium-term: from about 9.3 percent projected for 2011 to about 8 percent in 2016 . The baseline scenario also shows that a more favorable growth performance of the non hydrocarbon sector (of about 6 percent) would significantly reduce unemployment, bringing the unemployment rate to about 5 percent by 2016 .

43. However, these results may be optimistic given the continuous reduction in the responsiveness of employment to changes in economic activity that has occurred during the recent past. In fact, extending the trend of the estimated elasticity shown in Figure 4 up to 2016, and in absence of labor market reforms aimed at improving the responsiveness of unemployment to economic activity, the average employment-GDP elasticity over the period 2011-16 could be of about 0.4 . The evolution of unemployment under this assumption would be much less favorable. In particular, under the assumption of on an average growth rate of nonhydrocarbon GDP of about 5 percent, the unemployment rate would increase over the medium-term up to 11 percent. In addition, in order to reduce the unemployment rate to 5 percent by 2016 , the nonhydrocarbon sector would need to grow at an annual rate of about 8 percent.

\section{Unemployment-GDP elasticities}

44. An alternative way to project the evolution of unemployment over the medium term is to estimate unemployment-GDP elasticities (instead of employment-GDP elasticities). Figure 10 presents alternative scenarios of the evolution of unemployment and youth unemployment over the medium term under different unemployment and youth unemployment-GDP elasticities.

45. Under the baseline scenario, the elasticities are assumed to be those presented in Figure 5. Under this assumption, and an average growth rate of non hydrocarbon GDP of about 5 percent, the overall unemployment rate will decrease only slightly over the medium term while the youth unemployment will remain mostly stable. In addition, an improvement of potential growth from 5 to 7 percent would not be sufficient to significantly reduce youth unemployment. 
46. Under the alternative scenario, the elasticities are estimated assuming that labor market flexibility in Algeria would improve to the average level of other oil producers and emerging countries. Under this assumption, both unemployment and youth unemployment would decrease over the medium term. In addition, given that in Algeria youth unemployment has been less responsive to changes in economic activity, the reduction, in absolute terms, in youth unemployment over the medium term would be larger. In particular, while the total unemployment rate could fall from 10 percent in 2010 to 8.4 percent in 2016, the rate of youth unemployment could decrease from 21.5 percent in 2010 to 19 percent in 2016.

\section{F. Conclusions and Policy Implications}

47. Despite several years of sustained growth, the unemployment rate in Algeria remains high compared to other emerging economies. In addition, while growth performance in the last ten years was accompanied by a significant reduction in the overall unemployment rate, youth unemployment has proven more difficult to tackle as evidenced by the fact that the ratio of youth unemployment to overall unemployment has steadily increased over the recent period.

48. The results of the paper suggest that the relative low elasticity for youth employment is one of the main factors behind the still high level of youth unemployment and that labor market imperfections play an important role in explaining the low employment intensity of growth.

49. The descriptive evidence presented in the paper shows that Algeria's labor market is rigid both in absolute and relative terms (compared to other emerging counties), and therefore tends to favor insider versus outsider workers. The results of the empirical analysis suggest that reforms aimed at improving labor market flexibility may have important effects in reducing unemployment both in the short and in the medium term. In this context, reforms aimed at reducing search and hiring costs are particularly important to integrate young outsider workers into the labor market.

50. However, while labor market flexibility has an important role, the high level of unemployment among young graduates is also the result of mismatches between labor market demand and supply: on the one hand, the private sector has not been able to create sufficient demand for skilled workers; on the other hand, the distribution of Algerian students is highly unbalanced towards disciplines (such as humanities, social sciences, law and education) that generate an undersupply of the skills most needed by the private sector. In this context, properly designed active labor market policies can reduce unemployment by improving the efficiency of the job matching process and by enhancing the skills of the unemployed.

51. Reforms aimed at removing these labor market imperfections will also have an important effect in reducing the very long length of unemployment spells in the Algeria's labor market, as relative rigid labor markets and labor-market mismatches tend to reduce job 
turnover and increase the incidence of long-term unemployment. In fact, as evidenced by the results of the medium-term scenario analysis, in the absence of reforms aimed at improving the responsiveness of labor market conditions to changes in economic activity, unemployment is likely to remain high over the medium-term.

52. Finally, reforms aimed at improving the business climate and foster product market competition are key to increase labor demand over the medium-term. In particular, lower barriers to entry curb market power and incumbents' rents and tend to reduce wage claims and close the gap between productivity and real wages. Moreover, stronger competition may reduce bargaining positions of employer and increase employment costs for higher wage. Reduced rent sharing would also decrease the time spent for searching for employment opportunities in high wage sectors. 


\section{REFERENCES}

Afonso, A., and D. Furceri, 2010, "Government Size, Composition, Volatility, and Economic Growth," European Journal of Political Economy, 26(4), pp. 517-32.

Blanchard, Olivier, and Justin Wolfers, 2000, "The Role of Shocks and Institutions in the Rise of European Unemployment: The Aggregate Evidence," The Economic Journal, 110(462), pp. 1-33.

Bassanini, A., and R. Duval, 2006, "Employment Patterns in OECD Countries: Reassessing the Role of Policies and Institutions," OECD Economics Department Working Papers, No. 486, OECD Publishing. , 2009, "Unemployment, Institutions, and Reform

Complementarities: Reassessing the Aggregate Evidence for OECD Countries," Oxford Review of Economic Policy, Vol. 25, No. 1, pp.40-59.

Belot, Michèle, and Jan C van Ours, 2004, "Does the Recent Success of Some OECD Countries in Lowering their Unemployment Rates Lie in the Clever Design of their Labor Market Reforms?" Oxford Economic Papers, 56 (4), pp. 621-42.

Bernal-Verdugo, L., D. Furceri, and D. Guillaume, 2011, "Crises, Reforms, and Unemployment," IMF Working Papers (forthcoming) (Washington: International Monetary Fund).

Bernal-Verdugo, L., D. Furceri, and D. Guillaume, 2011, "Labor Market Flexibility and Unemployment: New Empirical Evidence of Static and Dynamics Effects," International Monetary Fund, unpublished.

Botero, Juan C., et al., 2004, “The Regulation of Labor." Quarterly Journal of Economics, Vol. 119 (4), 1339-82.

Bruno, S.F., et al., 2001, "Measuring the Effect of Globalization on Labor Demand Elasticity: an empirical application to OECD countries." FLOWENLA Discussion Paper 2.

Daveri, F., and G. Tabellini, 2000, "Unemployment, Growth and Taxation in Industrial Countries," Economic Policy.

Döpke, J., 2001, “The Employment Intensity of Growth in Europe," Kiel Working Paper No. 1021, Kiel Institute of World Economics. 
Elmeskov, Jørgen, Martin, John P., and Scarpetta, Stefano, 1998, "Key Lessons for Labour Market Reforms: Evidence from OECD Countries' Experiences," Swedish Economic Policy Review, Vol. 5 (2), pp. 205-52.

Feldmann, Horst, 2006, "Government Size and Unemployment: Evidence from Industrial Countries," Public Choice, Vol. 127 (3-4), pp. 451-67. ,2009, "The Unemployment Effects of Labor Regulation Around the World," Journal of Comparative Economics Vol. 37, 1: 76-90.

Howell, David, and Miriam Rehm, 2009, "Unemployment Compensation and High European Unemployment: a Reassessment with New Benefit Indicators," Oxford Review of Economic Policy, Vol. 25, No. 1, pp.60-93.

Kapsos, S., 2005, "The Employment Intensity of Growth: Trends and Macroeconomic Determinants," ILO Employment Strategy Papers No. 12.

ILO, 2011, ILO Estimates and Projections of the Economically Active Population: 1990-2020.

Mourre, G., 2004, "Did the Pattern of Aggregate Employment Growth Change in the Euro Area in the late 1990s?" European Central Bank Working Paper Series No. 358.

Nickell, S., 1997, "Unemployment and Labor Market Rigidities: Europe Versus North America," The Journal of Economic Perspectives, Vol. 11, No. 3.

Nickell, S., 1998, "Unemployment: Questions and Some Answers," The Economic Journal, Vol. 108, Issue 448 (May).

Nunziata, L., 2002, "Unemployment, Labour Market Institutions and Shocks," Nuffield College Working Papers in Economics, 2002-W16.

Roodman, D., 2009a, "How to Do xtabond2: An Introduction to Difference and System GMM in Stata," Stata Journal, Vol. 9(1), pp. 86-136.

2009b, "A Note on the Theme of Too Many Instruments," Oxford Bulletin of Economics and Statistics, Vol. 71 (1), pp. 135-58.

Stock, J.H., 1987, “Asymptotic Properties of Least Squares Estimators of Cointegrating Vectors.” Econometrica (55), 277-302. 
Table 1. Unemployment Statistics, 2010

\begin{tabular}{rccc}
\hline \multicolumn{4}{c}{ Unemployment Rate by Age Group and Gender } \\
\hline Overall & Overall & Male & Female \\
\cline { 2 - 4 } & 10.0 & 8.1 & 19.1 \\
Young (16-24) & 21.5 & 18.6 & 37.4 \\
Adults (25 and +) & 7.1 & 5.4 & 15.0 \\
\cline { 2 - 4 } & &
\end{tabular}

\begin{tabular}{|c|c|c|c|}
\hline \multicolumn{4}{|c|}{ Unemployment Rate by Degree of Instruction and Gender } \\
\hline & Overall & Male & Female \\
\hline Without instruction & 1.9 & 1.7 & 2.7 \\
\hline Primary & 7.6 & 7.5 & 8.0 \\
\hline Medium & 10.7 & 10.5 & 12.8 \\
\hline Secondary & 8.9 & 7.0 & 17.2 \\
\hline Superior & 20.3 & 10.4 & 33.3 \\
\hline \multicolumn{4}{|c|}{ Unemployment Rate by Areas (Rural vs. Urban) and Gender } \\
\hline & Overall & Male & Female \\
\hline Rural & 8.7 & 7.2 & 20.1 \\
\hline Urban & 10.6 & 8.6 & 18.8 \\
\hline Total & 10.0 & 8.1 & 19.1 \\
\hline
\end{tabular}

\begin{tabular}{r|ccc}
\hline \multicolumn{4}{c}{ Unemployment Rate by Duration (as \% of unemployment) and Gender } \\
\cline { 2 - 4 } Less than one year & Overall & Male & Female \\
12-23 Months & 35.6 & 33.8 & 35.6 \\
24 Month and more & 19.3 & 18.4 & 19.3 \\
Total & 45.1 & 47.8 & 45.1 \\
\cline { 2 - 4 } & 100 & 100 & 100 \\
\hline & \multicolumn{4}{|}{ Unemployment Rate for Graduates } \\
\cline { 2 - 4 } Overall & Male & Female \\
\cline { 2 - 4 } Humanities & 27.3 & 14.7 & 34.4 \\
Social Sciences & 28.7 & 14.0 & 43.7 \\
Sciences & 18.1 & 9.8 & 28.6 \\
Enginery & 14.8 & 9.4 & 39.7 \\
Total & 21.4 & 11.1 & 21.4 \\
\cline { 2 - 4 } & & &
\end{tabular}

Source: ONS.

CInternational Monetary Fund. Not for Redistribution 
Table 2. Labor Force Statistics, 2010

\begin{tabular}{cccc}
\hline & \multicolumn{3}{c}{ Labor force participation rate } \\
\hline & Overall & Male & Female \\
\hline 15 and + & 41.7 & 68.9 & 14.2 \\
$15-24$ & 28.2 & 46.5 & 8.9 \\
$25-54$ & 55.5 & 91.7 & 19.9 \\
$25-34$ & 57.5 & 90.8 & 23.9 \\
$35-54$ & 53.9 & 92.4 & 16.8 \\
$15-60$ & 45.9 & 75.0 & 15.7 \\
60 and + & 9.7 & 17.5 & 2.0 \\
\hline
\end{tabular}

Source: ONS.

Table 3. Employment Statistics, 2010

\begin{tabular}{|c|c|c|c|c|c|c|}
\hline & \multicolumn{6}{|c|}{ Employment by Sector and Gender } \\
\hline & \multicolumn{2}{|c|}{ Overall } & \multicolumn{2}{|c|}{ Male } & \multicolumn{2}{|c|}{ Female } \\
\hline & $\begin{array}{c}\text { Effective } \\
\text { (thousands) }\end{array}$ & Percent & $\begin{array}{c}\text { Effective } \\
\text { (thousands) }\end{array}$ & Percent & $\begin{array}{c}\text { Effective } \\
\text { (thousands) }\end{array}$ & Percent \\
\hline Agriculture & 1,136 & 11.7 & 1,040 & 12.6 & 95 & 6.5 \\
\hline Industry & 1,337 & 13.7 & 924 & 11.2 & 413 & 28.0 \\
\hline BTP & 1,886 & 19.4 & 1,860 & 22.5 & 25 & 1.7 \\
\hline \multirow[t]{4}{*}{ Services } & 5,377 & 55.2 & 4,436 & 53.7 & 941 & 63.8 \\
\hline & \multicolumn{6}{|c|}{ Employment Public vs. Private Sector and Gender } \\
\hline & \multicolumn{2}{|c|}{ Overall } & \multicolumn{2}{|c|}{ Male } & \multicolumn{2}{|c|}{ Female } \\
\hline & $\begin{array}{c}\text { Effective } \\
\text { (thousands) }\end{array}$ & Percent & $\begin{array}{c}\text { Effective } \\
\text { (thousands) }\end{array}$ & Percent & $\begin{array}{c}\text { Effective } \\
\text { (thousands) }\end{array}$ & Percent \\
\hline Public & 3,346 & 34.4 & 2671 & 32.3 & 95 & 45.8 \\
\hline Private & 6,390 & 65.6 & 5591 & 67.7 & 413 & 54.2 \\
\hline Total & 9,735 & 100 & 8261 & 100 & 25 & 100 \\
\hline
\end{tabular}

Source: ONS.

Table 4. Employment-GDP Elasticities

\begin{tabular}{|c|c|c|c|c|c|c|}
\hline Contemporaneous & $\begin{array}{c}\text { 1-year } \\
\text { ahead }\end{array}$ & $\begin{array}{c}\text { 2-year } \\
\text { ahead }\end{array}$ & $\begin{array}{c}\text { 3-year } \\
\text { ahead }\end{array}$ & $\begin{array}{c}\text { 4-year } \\
\text { ahead }\end{array}$ & $\begin{array}{c}\text { 5-year } \\
\text { ahead }\end{array}$ & Long-run \\
\hline 0.497 & $\begin{array}{c}0.715 \\
(3.519)^{* * *}\end{array}$ & $\begin{array}{c}0.811 \\
(5.692)^{* * *}\end{array}$ & $\begin{array}{c}0.853 \\
(8.544)^{* * *}\end{array}$ & $\begin{array}{c}0.872 \\
(10.852)^{* * *}\end{array}$ & $\begin{array}{c}0.880 \\
(11.836)^{\star * *}\end{array}$ & $\begin{array}{c}0.887 \\
(12.008)^{* * *}\end{array}$ \\
\hline
\end{tabular}

Note: t-statistics in parenthesis. ${ }^{* * *}$ denotes significance at 1 percent. 
Table 5. Unemployment and Labor Market Flexibility-Static Regression (OLS)

\begin{tabular}{|c|c|c|c|c|c|c|c|c|}
\hline & (I) & (II) & (III) & (IV) & $(\mathrm{V})$ & $(\mathrm{VI})$ & (VII) & (VIII) \\
\hline$\overline{L_{t}}$ & $\begin{array}{c}-0.567 \\
(-2.97)^{\star \star \star}\end{array}$ & $\begin{array}{c}-0.547 \\
(-2.86)^{\star \star *}\end{array}$ & $\begin{array}{c}-0.469 \\
(-2.33)^{\star *}\end{array}$ & $\begin{array}{c}-0.529 \\
(-2.72)^{\star * \star}\end{array}$ & $\begin{array}{c}-0.566 \\
(-2.84)^{\star \star *}\end{array}$ & $\begin{array}{c}-0.572 \\
(-3.03)^{\star * \star}\end{array}$ & $\begin{array}{l}-0.361 \\
(-1.61)^{*}\end{array}$ & $\begin{array}{l}-0.210 \\
(-0.88)\end{array}$ \\
\hline$L_{t}{ }^{*} D_{t}$ & $\begin{array}{c}-5.947 \\
(-31.10)^{\star * *}\end{array}$ & $\begin{array}{c}-5.193 \\
(-11.04)^{\star * *}\end{array}$ & $\begin{array}{c}-6.004 \\
(-31.94)^{\star * *}\end{array}$ & $\begin{array}{c}-5.974 \\
(-30.94)^{\star * *}\end{array}$ & $\begin{array}{c}-5.947 \\
(-29.70)^{\star \star *}\end{array}$ & $\begin{array}{c}-5.941 \\
(-31.39)^{\star * *}\end{array}$ & $\begin{array}{c}-6.153 \\
(-27.26)^{\star \star \star}\end{array}$ & $\begin{array}{c}-5.9712 \\
(-10.33)^{\star * *}\end{array}$ \\
\hline Output gap $_{t}$ & $\begin{array}{l}-0.041 \\
(-1.77)^{*}\end{array}$ & $\begin{array}{l}-0.013 \\
(-0.59)\end{array}$ & $\begin{array}{l}-0.038 \\
(-1.60)\end{array}$ & $\begin{array}{l}-0.043 \\
(-1.80)^{*}\end{array}$ & $\begin{array}{l}-0.042 \\
(-1.79)^{*}\end{array}$ & $\begin{array}{l}-0.044 \\
(-1.88)^{*}\end{array}$ & $\begin{array}{l}-0.038 \\
(-1.59)\end{array}$ & $\begin{array}{l}-0.013 \\
(-0.59)\end{array}$ \\
\hline Government size $_{\mathrm{t}}$ & - & $\begin{array}{c}2.736 \\
(1.78)^{*}\end{array}$ & - & - & - & - & - & $\begin{array}{l}2.326 \\
(1.47)\end{array}$ \\
\hline Openness $_{\mathrm{t}}$ & - & - & $\begin{array}{l}-0.865 \\
(-0.75)\end{array}$ & - & - & - & - & $\begin{array}{l}1.614 \\
(0.94)\end{array}$ \\
\hline Urban population $_{\mathrm{t}}$ & - & - & - & $\begin{array}{l}-3.054 \\
(-0.76)\end{array}$ & - & - & - & $\begin{array}{l}-2.221 \\
(-0.46)\end{array}$ \\
\hline Population density & - & - & - & - & $\begin{array}{l}0.145 \\
(0.06)\end{array}$ & - & - & $\begin{array}{c}9.598 \\
(2.02)^{\star *}\end{array}$ \\
\hline Crisis $_{t}$ & - & - & - & - & - & $\begin{array}{l}0.630 \\
(1.16)\end{array}$ & - & $\begin{array}{l}0.780 \\
(1.36)\end{array}$ \\
\hline Time trend ${ }_{t}$ & - & - & - & - & - & - & $\begin{array}{l}-0.053 \\
(-1.42)\end{array}$ & $\begin{array}{c}-0.186 \\
(-2.18)^{\star *}\end{array}$ \\
\hline$N$ & 893 & 893 & 893 & 882 & 882 & 893 & 893 & 882 \\
\hline $\mathrm{R}^{2}$ & 0.84 & 0.85 & 0.85 & 0.84 & 0.84 & 0.85 & 0.85 & 0.85 \\
\hline
\end{tabular}

Note: t-statistics in parenthesis based on robust clustered standard errors. ${ }^{*},{ }^{* *},{ }^{* * *}$ denote significance at 10 percent, 5 percent, 1 percent respectively.

Country fixed effects included. 
Table 6. Unemployment and Labor Market Flexibility-Dynamic Regression (GMM)

\begin{tabular}{|c|c|c|c|c|c|c|c|}
\hline & (I) & (II) & (III) & (IV) & $(\mathrm{V})$ & $(\mathrm{VI})$ & $(\mathrm{VII})$ \\
\hline $\mathrm{L}_{\mathrm{t}}$ & $\begin{array}{c}-0.316 \\
(-3.23)^{* \star *}\end{array}$ & $\begin{array}{c}-0.293 \\
(-3.30)^{\star * *}\end{array}$ & $\begin{array}{c}-0.301 \\
(-2.96)^{* * *}\end{array}$ & $\begin{array}{c}-0.232 \\
(-2.52)^{\star *}\end{array}$ & $\begin{array}{c}-0.277 \\
(-3.17)^{* * *}\end{array}$ & $\begin{array}{c}-0.287 \\
(-3.06)^{* * *}\end{array}$ & $\begin{array}{l}-0.137 \\
(-1.54)\end{array}$ \\
\hline$L_{t}^{*} D_{t}$ & $\begin{array}{c}-6.332 \\
(-2.38)^{\star *}\end{array}$ & $\begin{array}{c}-6.235 \\
(-2.57)^{\star \star *}\end{array}$ & $\begin{array}{c}-6.449 \\
(-2.63)^{\star \star *}\end{array}$ & $\begin{array}{c}-6.882 \\
(-2.98)^{\star * *}\end{array}$ & $\begin{array}{c}-6.781 \\
(-2.61)^{\star * *}\end{array}$ & $\begin{array}{c}-6.250 \\
(-2.88)^{\star \star *}\end{array}$ & $\begin{array}{c}-5.131 \\
(-2.24)^{\star *}\end{array}$ \\
\hline Unemployment $\mathrm{t}-1$ & $\begin{array}{l}-0.043 \\
(-1.56)\end{array}$ & $\begin{array}{l}-0.057 \\
(-2.10)^{* *}\end{array}$ & $\begin{array}{l}-0.084 \\
(-1.95)^{\star *}\end{array}$ & $\begin{array}{l}-0.058 \\
(-2.16)^{\star *}\end{array}$ & $\begin{array}{l}-0.058 \\
(-2.03)^{\star *}\end{array}$ & $\begin{array}{l}-0.063 \\
(-2.13)^{\star *}\end{array}$ & $\begin{array}{l}-0.046 \\
(-1.64)^{*}\end{array}$ \\
\hline Output gap ${ }_{t}$ & $\begin{array}{l}0.013 \\
(0.41)\end{array}$ & $\begin{array}{l}0.017 \\
(0.51)\end{array}$ & $\begin{array}{l}0.009 \\
(0.29)\end{array}$ & $\begin{array}{l}0.013 \\
(0.42)\end{array}$ & $\begin{array}{l}0.009 \\
(0.32)\end{array}$ & $\begin{array}{l}0.003 \\
(0.10)\end{array}$ & $\begin{array}{l}0.030 \\
(0.85)\end{array}$ \\
\hline Government size $_{\mathrm{t}}$ & - & $\begin{array}{l}0.787 \\
(1.45)\end{array}$ & - & - & - & - & - \\
\hline Openness $_{\mathrm{t}}$ & - & - & $\begin{array}{l}-0.682 \\
(-1.43)\end{array}$ & - & - & - & - \\
\hline Urban population $_{\mathrm{t}}$ & - & - & - & $\begin{array}{l}-3.054 \\
(-0.76)\end{array}$ & - & - & - \\
\hline Population density ${ }_{t}$ & - & - & - & - & $\begin{array}{l}0.062 \\
(0.49)\end{array}$ & - & - \\
\hline Crisis $_{t}$ & - & - & - & - & - & $\begin{array}{c}0.725 \\
(2.10)^{\star *}\end{array}$ & - \\
\hline Time trend $\mathrm{t}_{\mathrm{t}}$ & - & - & - & - & - & - & $\begin{array}{c}-0.055 \\
(-2.18)^{\star *}\end{array}$ \\
\hline $\mathrm{N}$ & 890 & 890 & 890 & 879 & 879 & 890 & 890 \\
\hline $\begin{array}{l}\text { Arellano-Bond, } A R(2) \\
\text { test, p-value }\end{array}$ & 0.513 & 0.504 & 0.551 & 0.506 & 0.523 & 0.538 & 0.470 \\
\hline Hansen test, p-value & 0.306 & 0.445 & 0.427 & 0.464 & 0.563 & 0.458 & 0.245 \\
\hline
\end{tabular}

Note: z-statistics in parenthesis. ${ }^{* * *},{ }^{* *},{ }^{*}$ denote significance at $1 \%, 5 \%$, and $10 \%$, respectively. GMM-System Estimator: Two-step using Windmeijer standard errors, all regressors considered as endogenous (instrumented using up to 2 lags). 
Table 7. Medium-term Scenario, 2011-16

\begin{tabular}{|c|c|c|c|c|c|c|}
\hline & 2011 & 2012 & 2013 & 2014 & 2015 & 2016 \\
\hline \multirow[t]{3}{*}{ Labor Force (millions) } & 10.997 & 11.329 & 11.569 & 11.802 & 12.029 & 12.252 \\
\hline & \multicolumn{6}{|c|}{ Baseline: Elasticity = 0.497} \\
\hline & \multicolumn{6}{|c|}{ Average growth $2011-16=5 \%$} \\
\hline Employed (millions) & 9.977 & 10.224 & 10.478 & 10.738 & 11.005 & 11.278 \\
\hline \multirow[t]{2}{*}{ Unemployment rate (\%) } & 9.278 & 9.750 & 9.432 & 9.015 & 8.518 & 7.947 \\
\hline & \multicolumn{6}{|c|}{ Average growth $2011-16=6 \%$} \\
\hline Employed (millions) & 10.025 & 10.324 & 10.631 & 10.948 & 11.274 & 11.610 \\
\hline \multirow[t]{3}{*}{ Unemployment rate (\%) } & 8.532 & 8.574 & 7.842 & 7.004 & 6.080 & 5.075 \\
\hline & \multicolumn{6}{|c|}{ Alternative: Elasticity $=0.379$} \\
\hline & \multicolumn{6}{|c|}{ Average growth $2011-16=5 \%$} \\
\hline Employed (millions) & 9.920 & 10.108 & 10.301 & 10.496 & 10.696 & 10.899 \\
\hline \multirow[t]{2}{*}{ Unemployment rate (\%) } & 9.793 & 10.773 & 10.968 & 11.066 & 11.088 & 11.042 \\
\hline & \multicolumn{6}{|c|}{ Average growth $2011-16=8 \%$} \\
\hline Employed (millions) & 10.027 & 10.328 & 10.638 & 10.958 & 11.287 & 11.625 \\
\hline Unemployment rate (\%) & 8.512 & 8.535 & 7.783 & 6.924 & 5.979 & 4.952 \\
\hline
\end{tabular}

Source: ONS, ILO and Author's calculations. 
Figure 1. Demographic Indicators

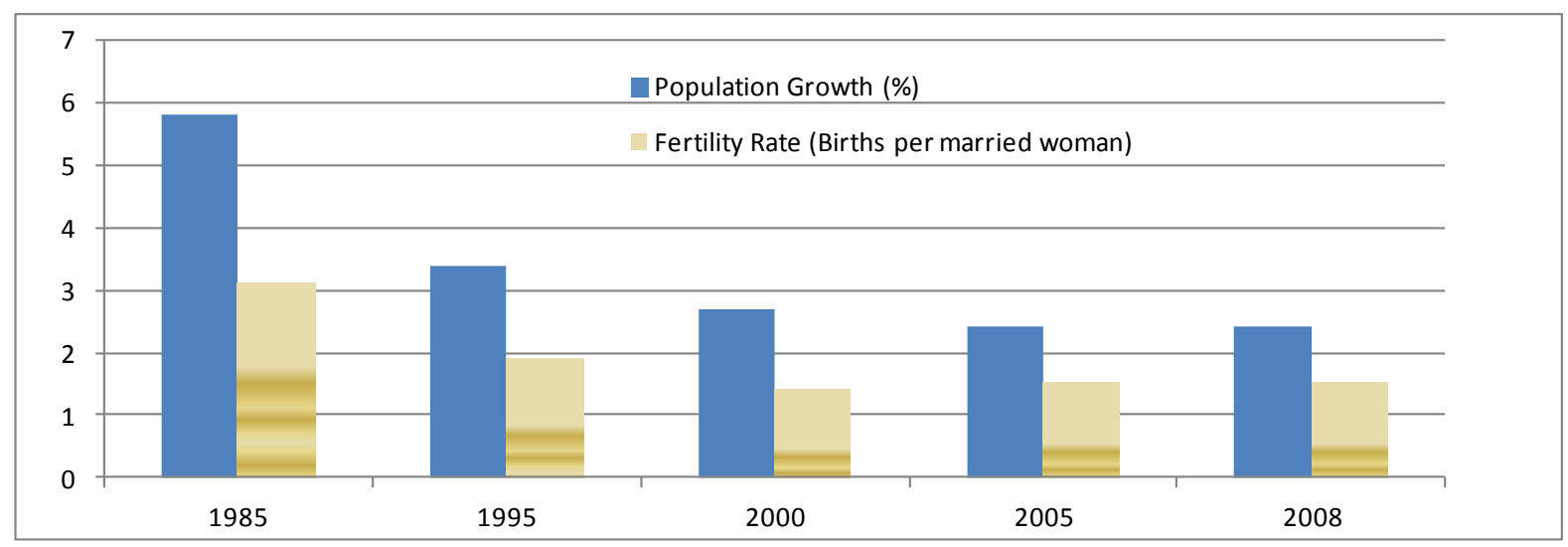

Figure 2. Evolution of Unemployment over Time

Panel A

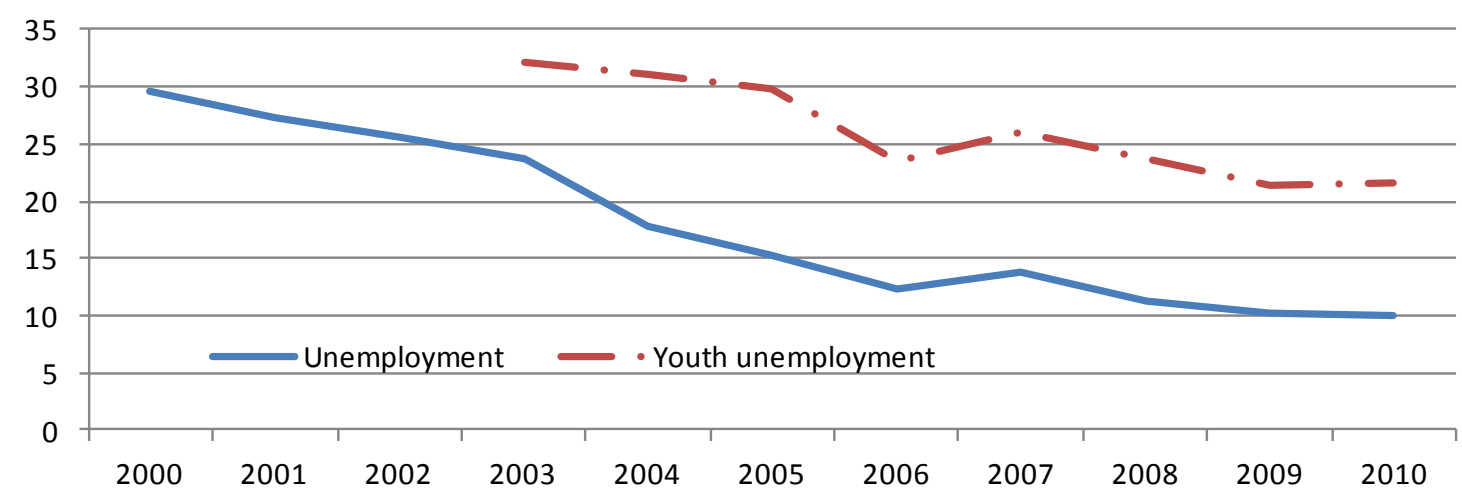

Panel B

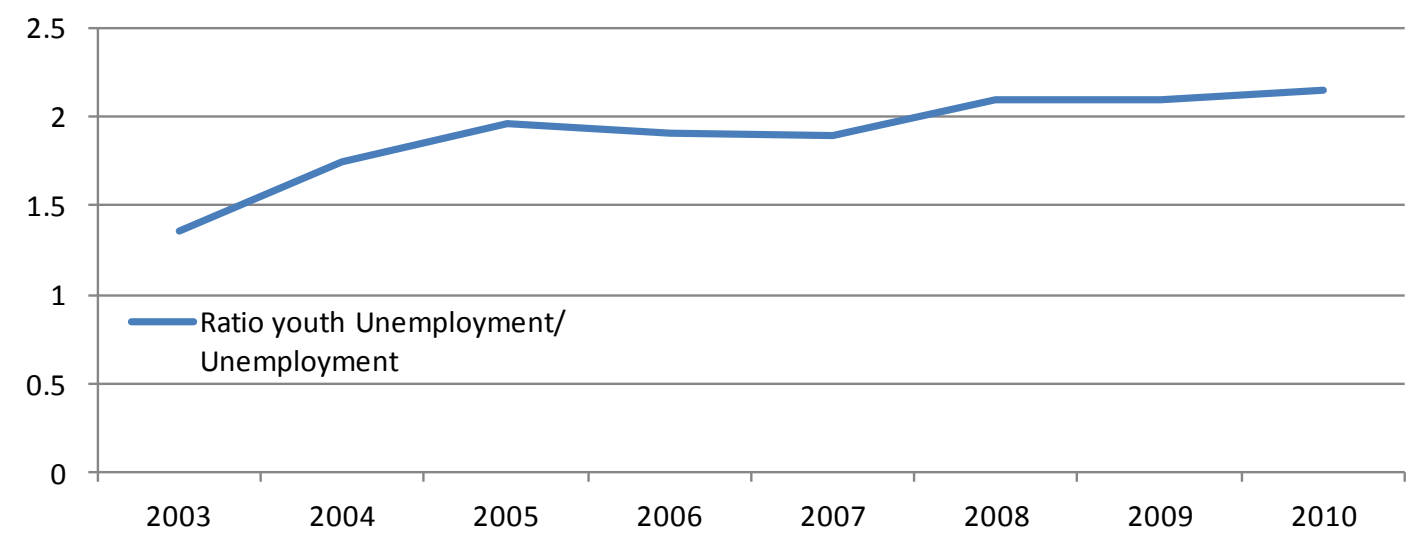

Source: ONS, Author calculation. 
Figure 3. Employment and GDP over Time

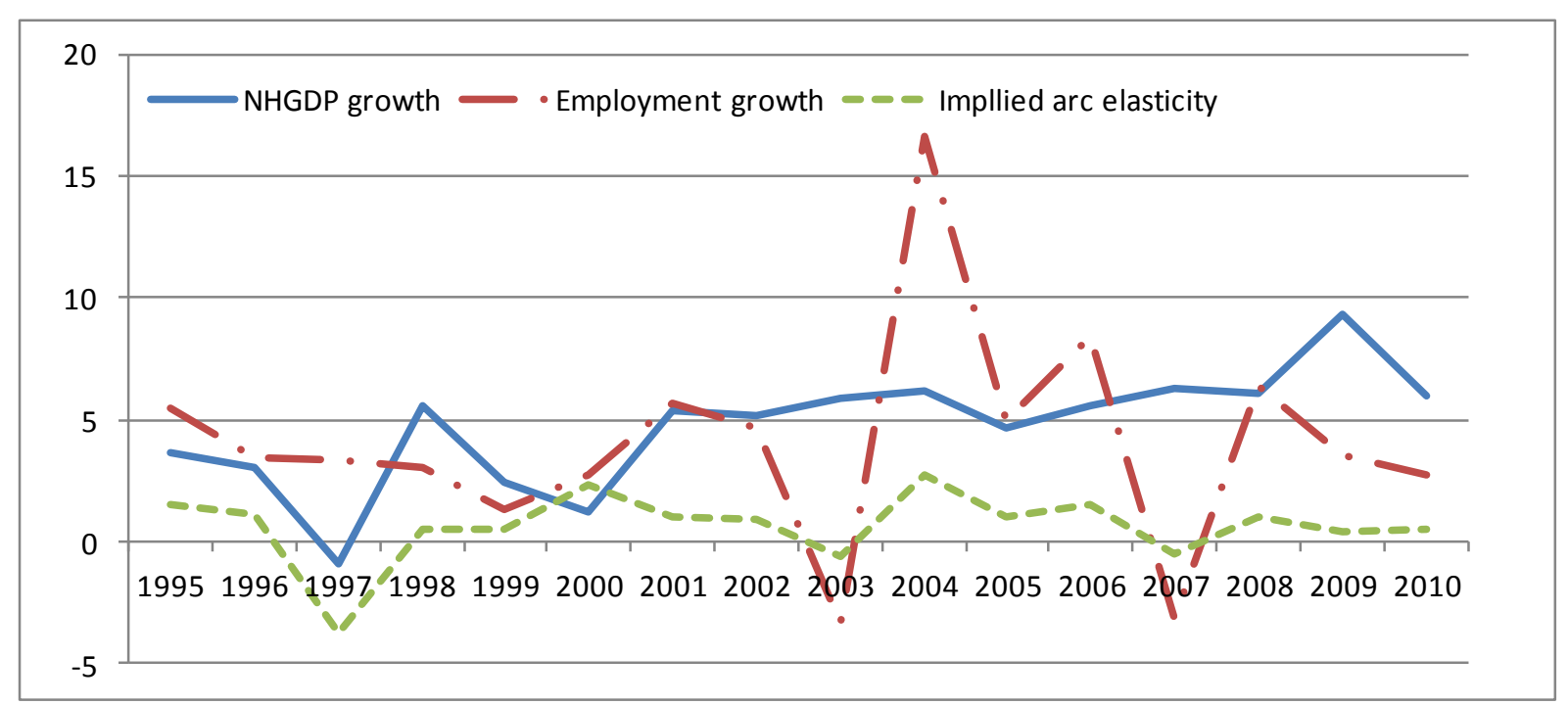

Source: ONS, WDI, Author calculation.

Figure 4. Arc Elasticities by Age Groups

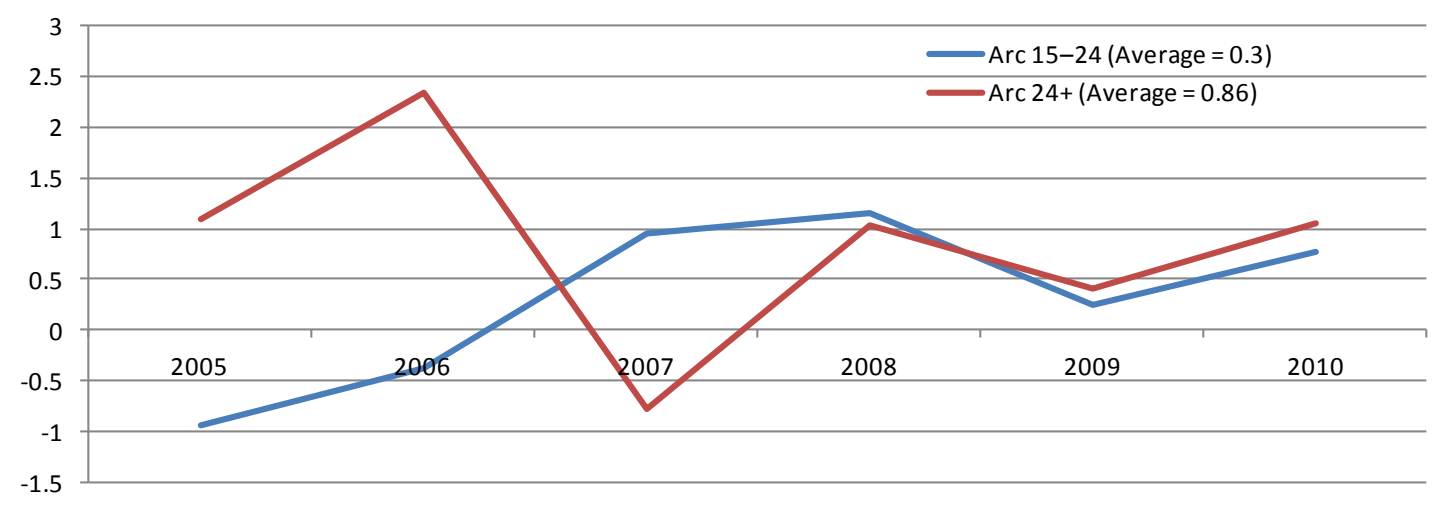

Source: ONS, WDI, Author calculation. 
Figure 5. Arc Elasticities by Sectors

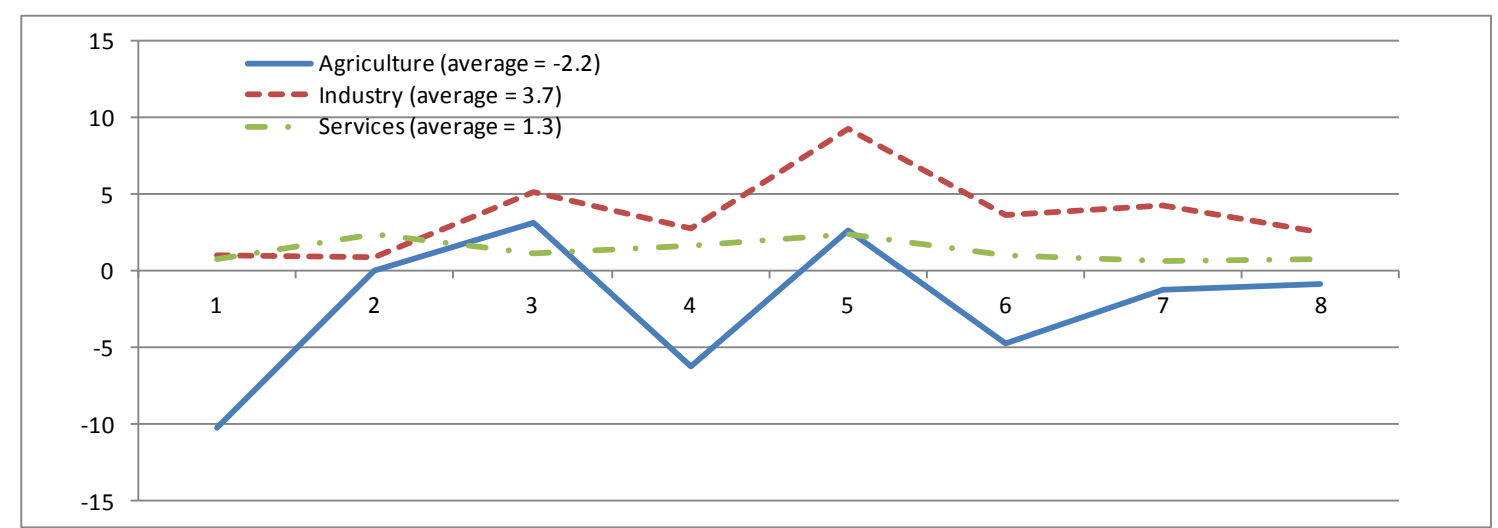

Source: ONS, WDI, Author calculation.

Figure 6. Recursive Estimates of Elasticities

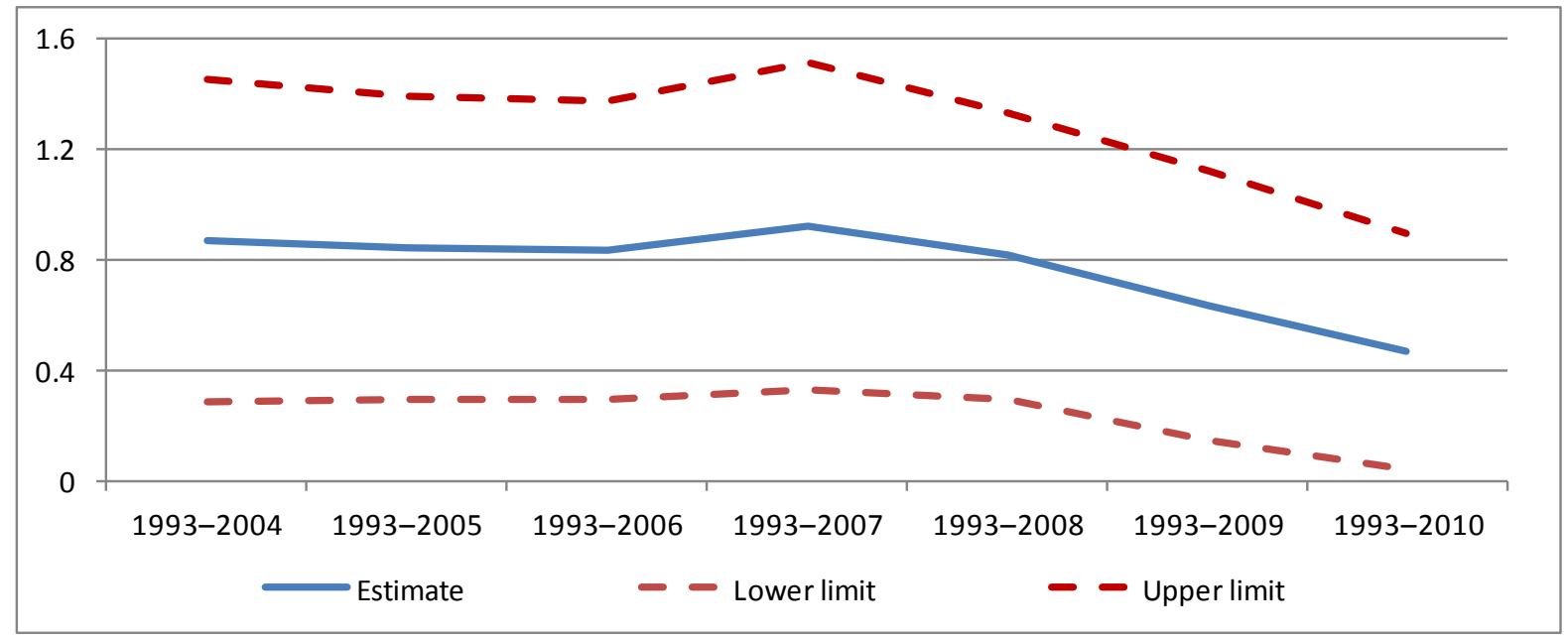

Figure 7. Labor Market Flexibility in Algeria, 2008

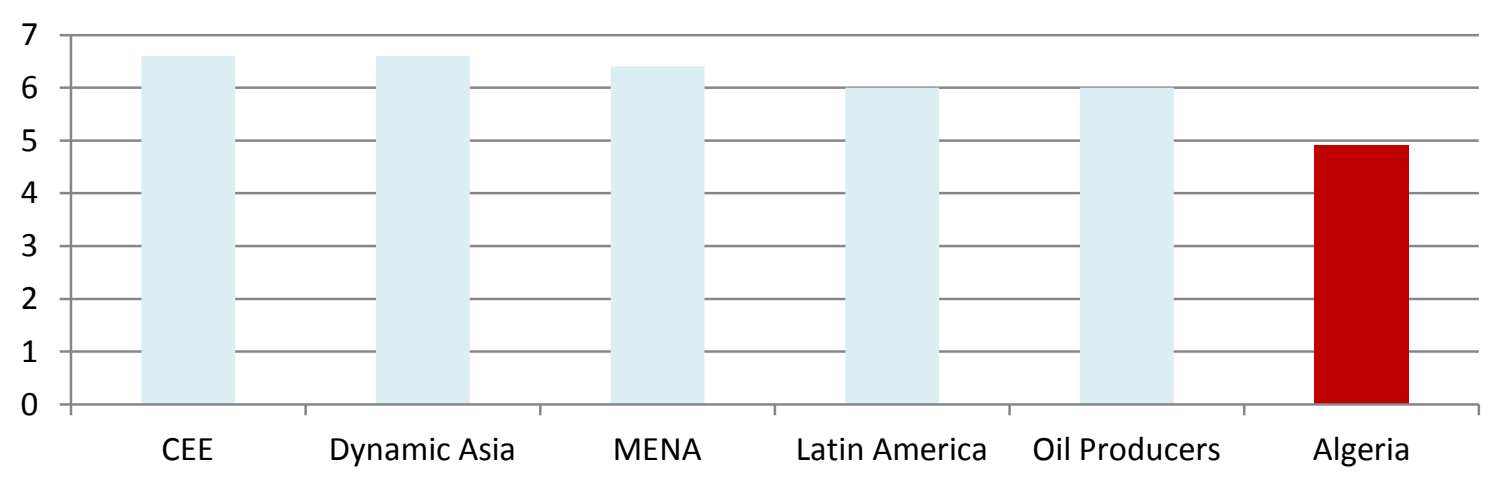

CInternational Monetary Fund. Not for Redistribution 
Figure 8. Evolution of Labor Market Flexibility over Time

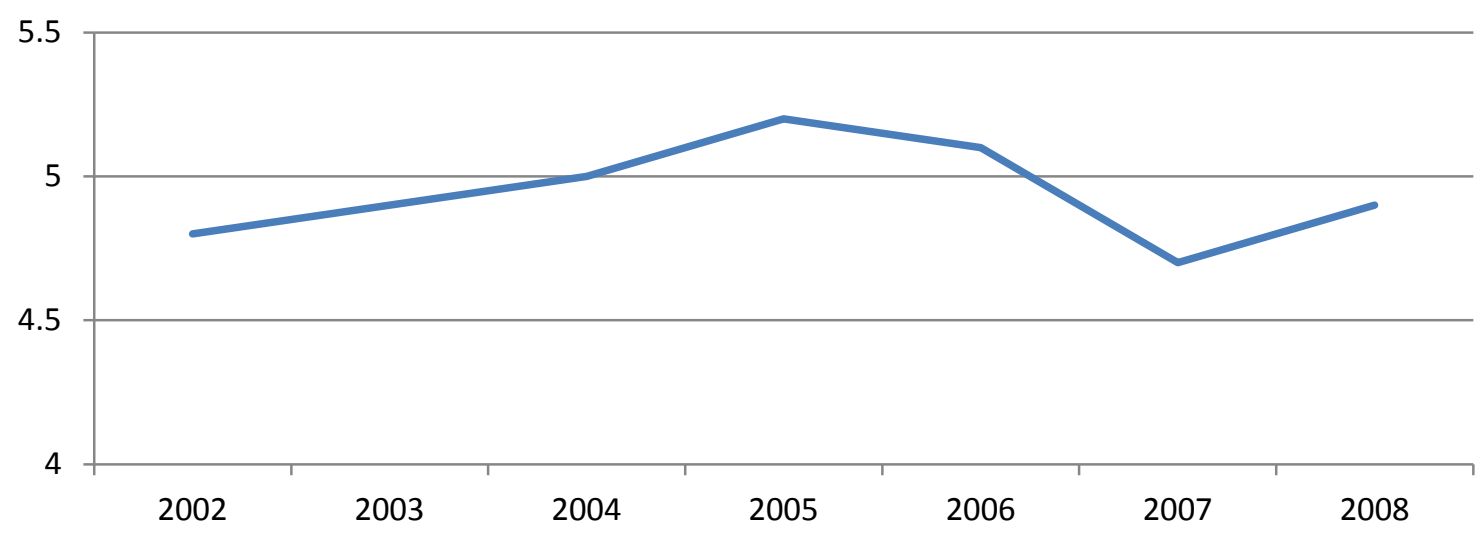

Figure 9. Elasticity Unemployment-Output

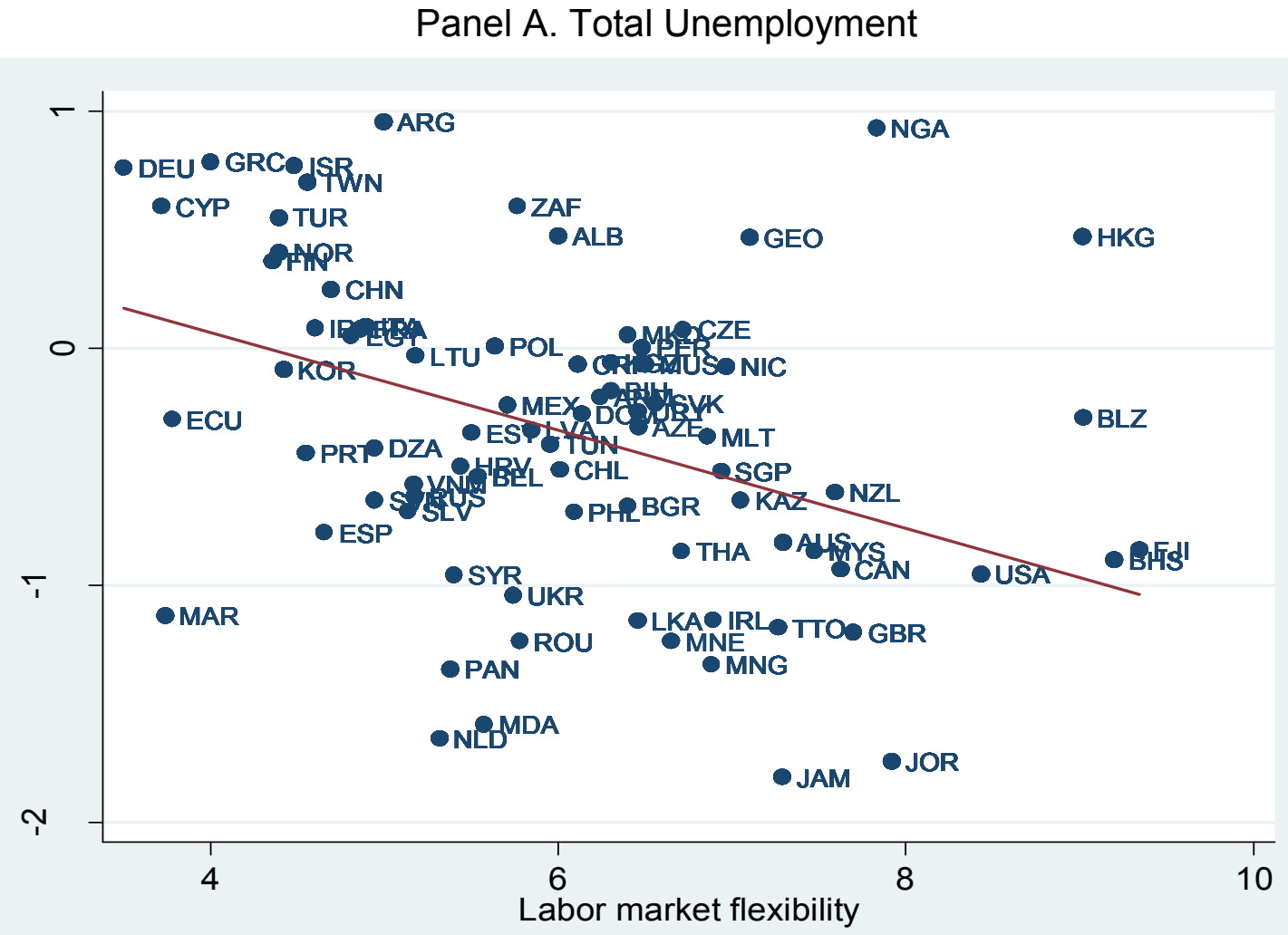

CInternational Monetary Fund. Not for Redistribution 
Panel B. Youth Unemployment

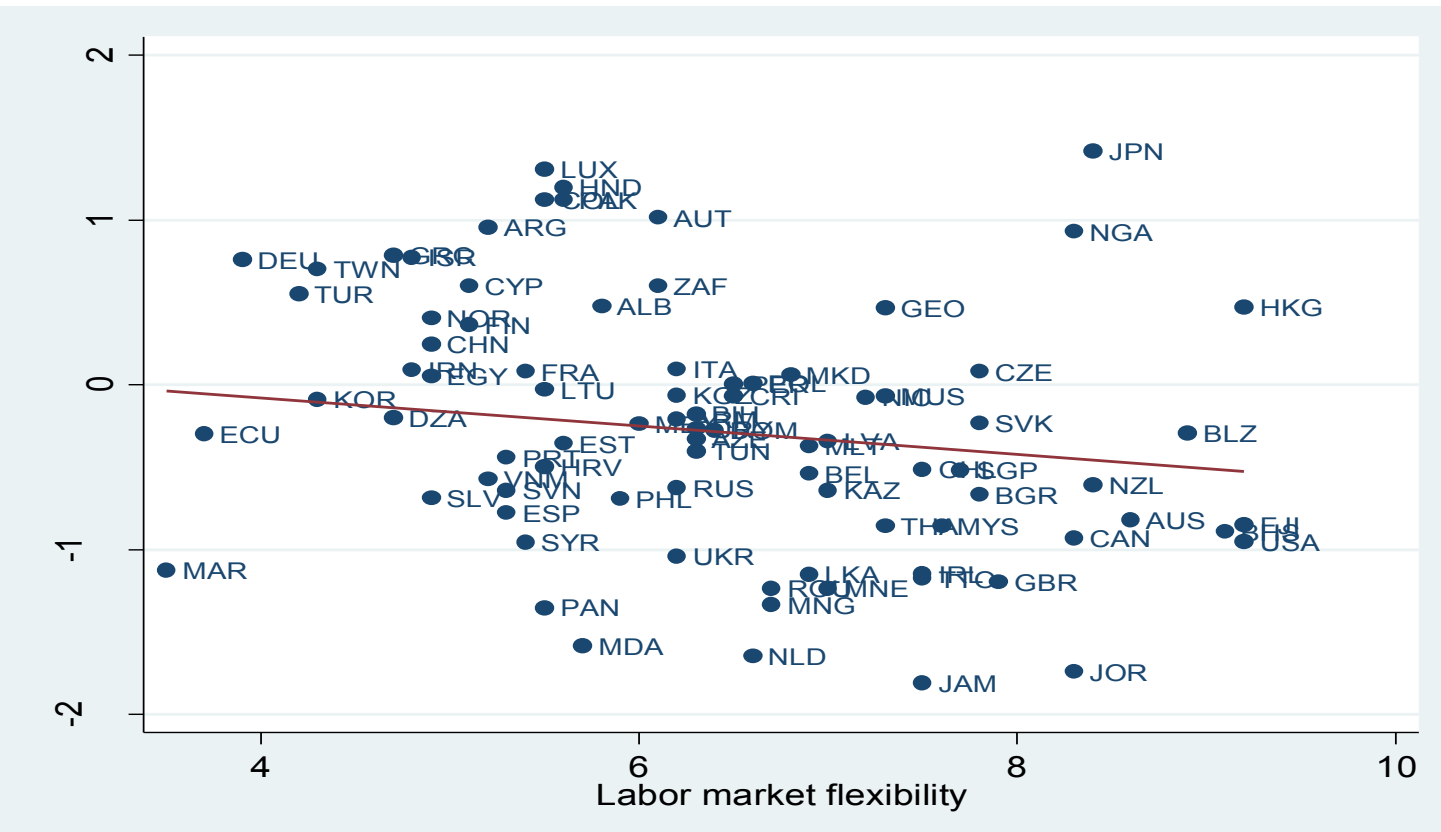

Figure 10. Labor Market Flexibility and Medium-term Unemployment Panel A. Total Unemployment]

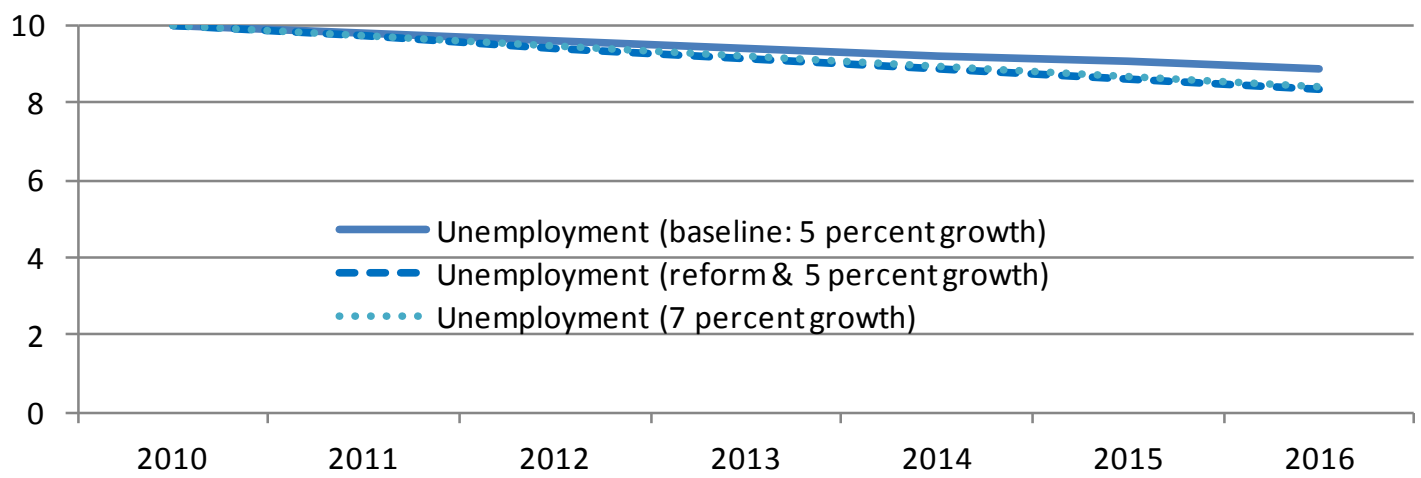

Panel B. Youth Unemployment

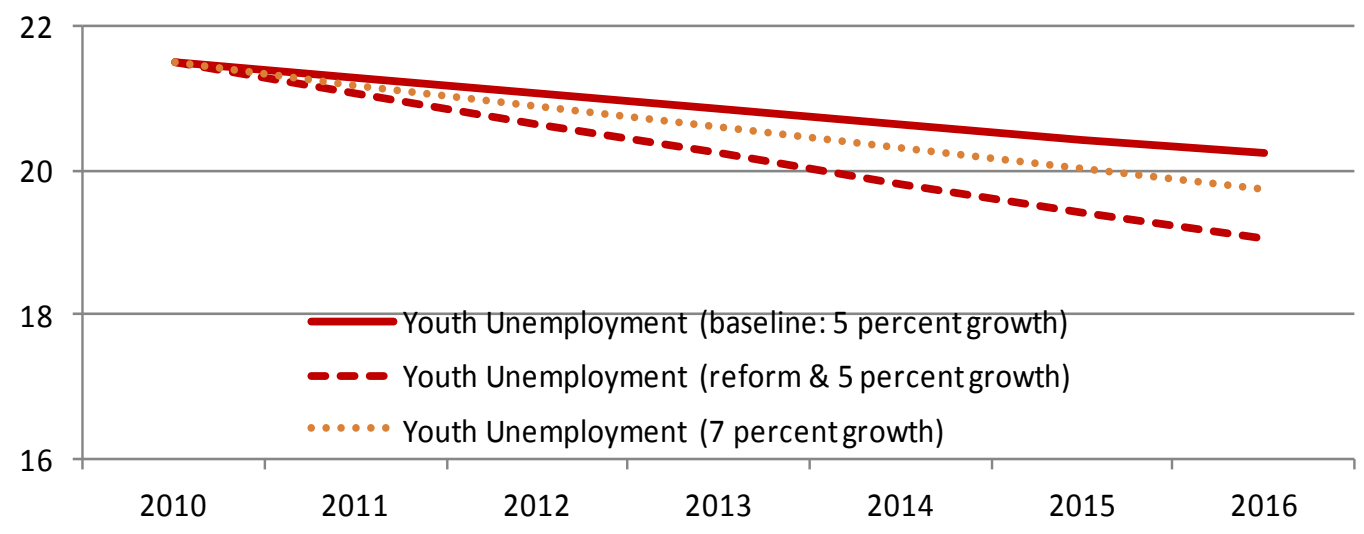

CInternational Monetary Fund. Not for Redistribution 


\section{OPTIMAL INTERNATIONAL RESERVES IN ALgERIA ${ }^{1}$}

\section{A. Introduction}

1. During the past decade, Algeria has built substantial international reserves, which by the end of 2010 were around US\$162 billion (103 percent of GDP). This massive accumulation of reserves has been the result of generally prudent macroeconomic management in the context of high hydrocarbon prices, Algeria's most important export sector (Figure 1). While the global economic crisis of 2008-09 has shown the importance of holding an adequate level of reserves, it has also raised questions about the adequacy of Algeria's reserve level. However, there is little consensus among policymakers on what constitutes an adequate level from a precautionary perspective (IMF, 2011).

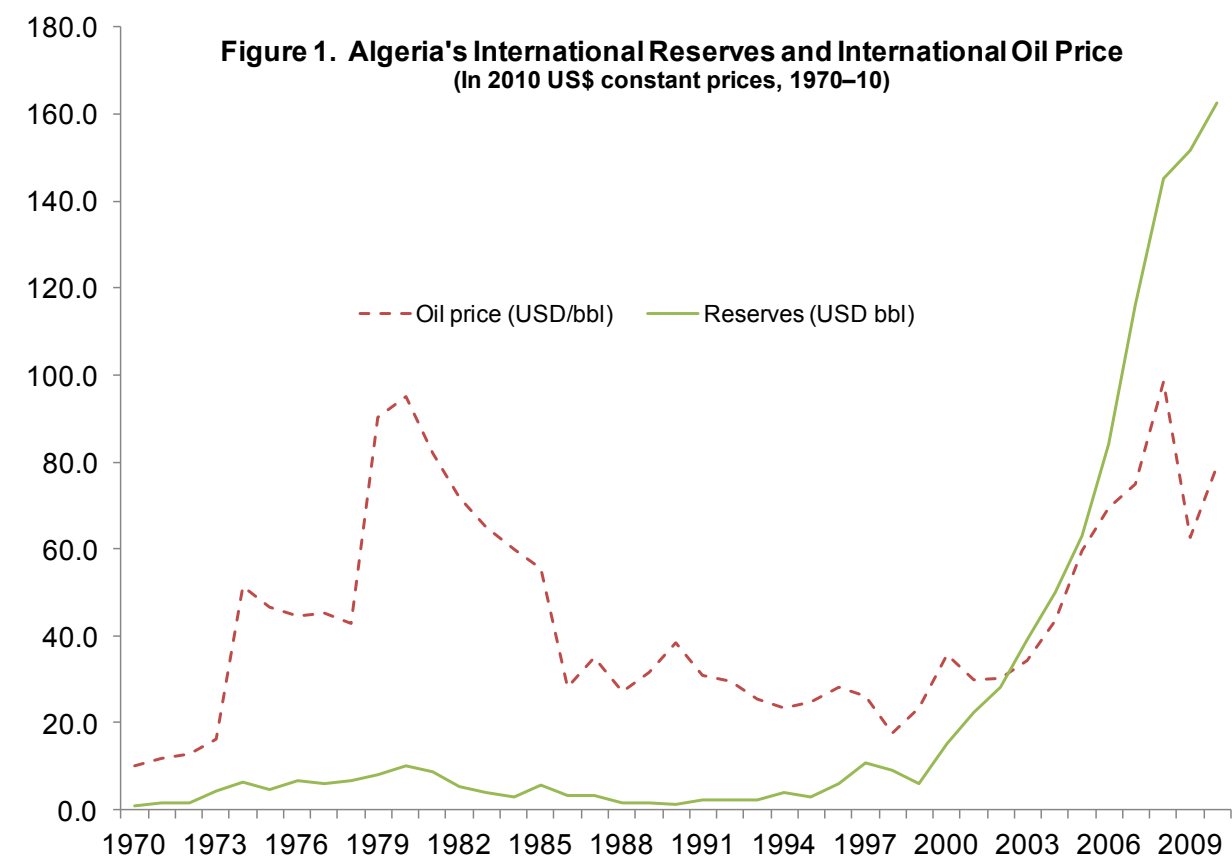

Sources: Algerian authorities; and International Financial Statistics.

2. The traditional literature on reserve adequacy dates back to 40 years ago and focuses on current account sustainability issues (Jeanne and Rancière, 2006). A more recent strand of the literature analyses the massive reserve accumulation in emerging markets during the 2000s as a response to balance of payments crises, considering shocks to both the current and capital accounts (Jeanne and Rancière, 2006; Jeanne, 2007; Dehesa et al., 2009; and Valencia, 2010). The task of assessing reserve adequacy is even more difficult for countries exporting exhaustible natural resources since this reserve accumulation is in good part to

\footnotetext{
${ }^{1}$ Prepared by Jose Gijon and Ernesto Crivelli (both MCD).
} 
save for the period after the exhaustion of resources (Takizawa, 2005, Carvalho Filho, 2007 and Thomas et al., 2008).

3. This paper assess whether the level of reserve accumulation in Algeria is consistent with the use of exhaustible hydrocarbon resources across generations. It exams the case of a large hydrocarbon exporter, Algeria, which has been accumulating, like most oil and gas exporters, massive reserves during the past decade, an accumulation which are well beyond what is required to absorb current and capital account shocks.

4. Hence, this paper analyzes the level of Algeria's optimal reserves (or reserve adequacy) using three different approaches. First as a first stage reference, it compares the level of reserves in Algeria with those of other emerging markets using metrics and benchmarks traditionally used to assess the level of reserves against current or capital account shocks. Not surprisingly, it shows that Algeria's reserves are now well above the traditional benchmarks for reserve adequacy. The paper then turns to a second approach in which it estimates a reserve demand model using standard econometric techniques to assess the main determinants of actual reserve holdings in a panel of countries with similar economic characteristics to those of Algeria. This traditional model again, cannot explain the massive accumulation of reserves in Algeria since the early 2000s.

5. Finally, a model based on the permanent income approach is considered, to gauge the level of reserves in Algeria. This final part of the analysis rests on the assumption that a country like Algeria is endowed with nonrenewable resources (i.e., hydrocarbons), and policymakers have to confront an equity problem in both the short and the long run in order to ensure intergenerational equity in the use of these resources. This policy trade-off can have important consequences in policy implementation and may require a higher level of reserves than those traditionally assumed in the empirical research. This approach shows that Algeria's reserve accumulation has been broadly in line with the norm based on the permanent income framework, and that maintaining the expansionary fiscal stance of last year over the long-term would bring reserves accumulation well below that norm in the future. 


\section{B. Traditional Measures for Assessing Reserve Adequacy}

\section{Traditional benchmarks ${ }^{2}$}

6. The traditional purpose of holding international reserves has been to absorb balance of payments shocks when the exchange rates cannot ensure the adjustment or when there is limited access to international borrowing. Countries that are confronted with these types of policy constraints usually have either a rigid exchange rate regime (fixed exchange regimes, currency boards, or narrow managed floats) or a repressed and/or low-integrated financial sector. The three traditional measures for capturing vulnerability to external shocks are: (i) reserves-to -imports ratio, (ii) reserves-to-short-term debt, and (iii) reserves to money aggregates (see Annex I).

7. Table 1 presents in reserve adequacy ratios for a selected group emerging countries: Middle East and North Africa (MENA) oil exporters, MENA oil importers and non-MENA oil exporters. It shows that the massive accumulation of reserves due to the high oil prices of the past decade has resulted in very high coverage ratio for most oil exporters. The reserves to imports ratio is well above the 3 months of imports coverage, the generally accepted minimum threshold, for all oil exporters with the exception of Sudan. Similarly, the oil exporters have very high reserve coverage ratios for the other two benchmarks, reserves to short-term debt and reserves to M2 ratios. If we consider the additional reserves available in public saving vehicles like SWF, the reserves to short-term debt and reserves to M2 ratios are above the generally accepted minimum thresholds of respectively 1 percent and 20 percent for all oil exporters.

\footnotetext{
${ }^{2}$ International reserves data for certain oil-exporting countries are likely to be underestimated due to the existence of public saving vehicles, usually a sovereign wealth fund, where large shares of export receipts are deposited and reinvested in other types of assets. In this cross-country comparison, Bahrain, Kuwait, Qatar, and the United Arab Emirates are the most notable examples. Each country has a sovereign wealth fund which invests in a large array of assets. The variation in the degrees of liquidity of these investments (ranging from cash to real estate investments) limits their capacity to provide additional funds that could increase reserve adequacy levels. Data are scarce, but highly liquid assets (i.e., cash, stocks, and bonds) represent on average 50 percent to 65 percent of total assets (Sensenbrenner, 2010, and The Monitor Company, 2011). Reserve adequacy estimates for 2010, adjusting for assets held in sovereign wealth funds by Bahrain, Kuwait, Qatar and the United Arab estimates, are presented in Annex II.
} 
Table 1. Reserve Adequacy Ratios for Selected Emerging Economies

\begin{tabular}{lccc}
\hline & $\begin{array}{c}\text { International } \\
\text { reserves to } \\
\text { imports ratio } \\
\mathbf{( 2 0 1 0 )}^{\mathbf{1 /}}\end{array}$ & $\begin{array}{c}\text { International } \\
\text { reserves to short- } \\
\text { term debt ratio } \\
\mathbf{( 2 0 1 0 )}^{\mathbf{2 l}}\end{array}$ & $\begin{array}{c}\text { Int. reserves to M2 } \\
\text { ratio (2010) }\end{array}$ \\
\hline MENA oil and gas exporters & 38.7 & 545.4 & 147.6 \\
Algeria & 3.2 & $\ldots$ & $\ldots$ \\
Bahrain & 12.5 & 23.2 & $\ldots$ \\
Iran & 9.4 & 1.4 & 23.9 \\
Kuwait & 38.2 & 58.9 & 256.4 \\
Libya & 6.0 & 1.9 & 57.0 \\
Oman & 6.2 & 1.1 & 42.7 \\
Qatar & 25.4 & 10.1 & 154.2 \\
Saudi Arabia & 1.0 & $\ldots$ & $\ldots$ \\
Sudan & 8.4 & 0.8 & 20.0 \\
United Arab Emirates & 7.8 & $\ldots$ & 56.8 \\
Yemen & & & \\
MENA oil and gas importers & 6.0 & 376.1 & \\
Morocco & 5.5 & 2.1 & 31.6 \\
Tunisia & & & \\
Other oil and gas exporters & 3.7 & $\ldots$ & 57.5 \\
Angola & 8.4 & 1.7 & 45.3 \\
Nigeria & 5.3 & & $\ldots$ \\
Venezuela & & & \\
\hline 1/ In months of imports. & & & \\
2/ In times of total short-term debt. & & & \\
3/ In percent of M2. & & & \\
\hline
\end{tabular}

\section{Composite benchmarks}

\section{Benchmarks based on Wijnholds and Kapteyn (2001)}

8. Although the ratios presented in the previous section are the standard measures of reserve adequacy, some composite benchmarks using these three ratios are used in the empirical literature. Most prominently, Wijnholds and Kapteyn (WK, 2001) suggest a benchmark that assumes coverage of short-term debt and only a fraction of the money aggregate (i.e., around 10-20 percent), adjusted by the country risk index. The authors argue that assuming full coverage of the money aggregate (as suggested by De Gregorio et al., 1999) may be too extreme for countries with a pegged or managed float exchange rate system. Also, the adjustment for risk is important given that not all countries are equally vulnerable to capital flight. 
Table 2. Algeria's WK Composite Reserve Adequacy Indicator

\begin{tabular}{|c|c|c|c|c|c|c|}
\hline & $\begin{array}{c}\text { Short- } \\
\text { term debt } \\
(1)\end{array}$ & $\begin{array}{l}M 2^{*} 20 \% * \\
\text { Average } \\
\text { risk }(2 \mathrm{~A})\end{array}$ & $\begin{array}{c}\mathrm{M} 2^{*} 20^{*} \\
100 \% \text { risk } \\
(2 \mathrm{~B})\end{array}$ & $\begin{array}{l}\text { Adequate } \\
\text { reserves } \\
\text { average } \\
\text { risk } 3 \mathrm{~A} \\
=(1+2 \mathrm{~A})\end{array}$ & $\begin{array}{l}\text { Adequate } \\
\text { reserves } \\
\text { with } \\
100 \% \text { risk } \\
3 \mathrm{~B}= \\
(1+2 \mathrm{~B})\end{array}$ & $\begin{array}{l}\text { Actual } \\
\text { reserves } \\
(4)\end{array}$ \\
\hline & \multicolumn{6}{|c|}{ USD billion } \\
\hline $2000-05$ & 0.6 & 2.6 & 8.2 & 3.2 & 8.9 & 31.0 \\
\hline 2006 & 0.1 & 3.0 & 13.6 & 3.1 & 13.6 & 77.9 \\
\hline 2007 & 0.6 & 4.1 & 17.9 & 4.7 & 18.6 & 110.3 \\
\hline 2008 & 0.3 & 3.9 & 16.8 & 4.2 & 17.1 & 143.2 \\
\hline 2009 & 0.3 & 5.6 & 19.2 & 5.9 & 19.4 & 149.0 \\
\hline 2010 & 0.3 & 6.2 & 21.1 & 6.5 & 21.4 & 162.6 \\
\hline
\end{tabular}

9. The composite indicator of WK, applied to Algeria, shows that the level of reserves far exceeds the level required to fight potential capital flight. In the case of Algeria, the minimum adequate level of reserves is assessed using the average of the Economist country risk index and the index of the International Country Risk Guide (ICRG), and the maximum fraction of M2 to be backed by reserves suggested by WK, (i.e. 20 percent). The estimation also assumes that Algeria faces the maximum possible risk level (i.e., 100 percent). Table 2 presents the evolution of the WK composite benchmark during the 2000s, showing that reserve adequacy has more than doubled over the decade using both measures of the WK indicator (column 3A and 3B). In Figure 2, a cross-country comparison also shows that in 2010, Algeria's WK composite indicator is larger than the average value for selected MCD oil exporters, MCD oil importers, and non-MCD oil exporters.

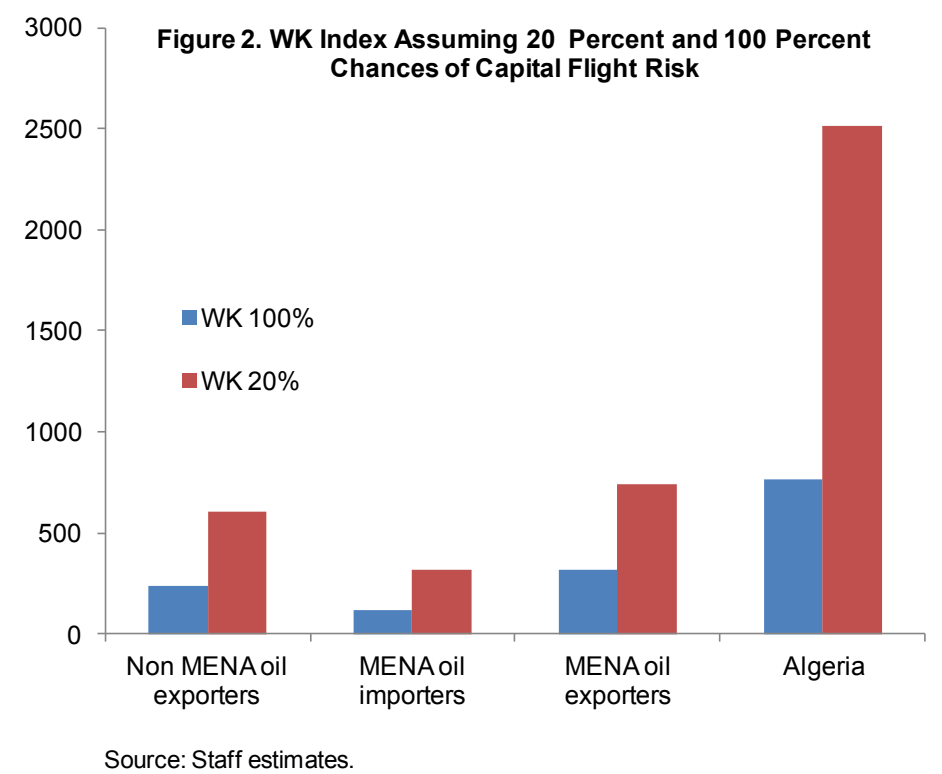


10. A second composite benchmark for assessing reserve adequacy consists of the aggregate of total short-term debt, three months of imports of goods and services, and the WK composite assuming two different capital flight scenarios. Table 3 presents the results for Algeria, showing very high reserve adequacy ratios.

Table 3. Algeria's WK Composite Reserve Adequacy Indicator with Three Months Import Coverage

\begin{tabular}{|c|c|c|c|c|c|c|c|}
\hline & $\begin{array}{l}\text { Short-term } \\
\text { debt (1) }\end{array}$ & $\begin{array}{l}\text { Required } \\
\text { reserves to } \\
\text { cover } 3 \\
\text { months of } \\
\text { imports } \\
(2)\end{array}$ & $\begin{array}{c}M 2 * 20 \% * \\
\text { ICRG } \\
(2 A)\end{array}$ & $\begin{array}{c}\mathrm{M} 2^{*} 20^{*} \\
100 \% \text { risk } \\
(2 \mathrm{~B})\end{array}$ & $\begin{array}{c}\text { Adequate } \\
\text { reserves } \\
\text { average risk } \\
3 \mathrm{~A}=(1+2 \mathrm{~A})\end{array}$ & $\begin{array}{c}\text { Adequate } \\
\text { reserves } \\
\text { with } 100 \% \\
\text { risk } 3 \mathrm{~B}= \\
(1+2 \mathrm{~B})\end{array}$ & $\begin{array}{c}\text { Actual } \\
\text { reserves } \\
(4)\end{array}$ \\
\hline & \multicolumn{7}{|c|}{ USD billion } \\
\hline $2000-05$ & 0.6 & 4.2 & 2.6 & 8.2 & 11.8 & 17.5 & 31.0 \\
\hline 2006 & 0.1 & 6.4 & 3.0 & 13.6 & 17.3 & 27.8 & 77.9 \\
\hline 2007 & 0.6 & 8.3 & 4.1 & 17.9 & 27.1 & 40.9 & 110.3 \\
\hline 2008 & 0.3 & 11.9 & 3.9 & 16.8 & 39.3 & 52.2 & 143.2 \\
\hline 2009 & 0.3 & 11.9 & 5.6 & 19.2 & 43.1 & 56.6 & 149.0 \\
\hline 2010 & 0.3 & 12.6 & 6.2 & 21.1 & 42.3 & 57.2 & 162.6 \\
\hline
\end{tabular}

\section{The IMF reserve adequacy assessment tool}

11. A recent two-step approach has been proposed by the IMF (2011) for assessing reserve adequacy. The first stage consists of estimating the relative risk posed by four main indicators (exports, broad money, short-term debt, and other portfolio liabilities) on the level of reserves. This risk is based on observed distributions of outflows from each source during periods of exchange market pressure. With this information, a "risk-weighted liability stock" is constructed based on historic drains observed at the tenth percentile of each of the distributions. Depending on the exchange rate arrangement, the resulting composite metric is the following:

Fixed: $\quad 30 \%$ of STD $+15 \%$ of OPL $+10 \%$ of M $2+10 \%$ of $\mathrm{X}^{3}$

Floating: $\quad 30 \%$ of STD $+10 \%$ of OPL $+5 \%$ of M $2+5 \%$ of X

12. In the second stage, the composite metric implying the optimal level of reserves is assessed based on past crisis experience. For that purpose, the proposed metric has been tested against three parameters: (i) reducing crisis probability, (ii) avoiding abrupt fall in consumption during a crisis, and (iii) the correlation with reserve losses during a crisis. The analysis shows that the proposed metric outperforms other metrics in all three parameters. The authors suggest that a level of coverage between 100 and 150 percent of the proposed metric should be regarded as adequate for a typical country. A preliminary calculation for

\footnotetext{
${ }^{3}$ Where: STD stands for short-term debt, OPL other portfolio liabilities, M2 broad money, and X exports.
} 
Algeria shows that the level of international reserves in 2010 is between 9 (fixed) and 19 (floating) times the level suggested by the proposed metric, depending on the exchange rate arrangement assumed.

\section{Standard Econometric Analysis}

13. A complementary approach to gauging the adequacy of international reserves consists of identifying the driving forces behind reserve accumulation. A reserve demand model is estimated in this section for an unbalanced panel of 17 countries, either with similar economic characteristics, or relevant to Algeria from a regional perspective. ${ }^{4}$ The model uses annual data for the period 1970-2009.

14. The model aims at identifying potential determinants of reserve accumulation. To capture the effect of the volatility of the shocks faced by the economy on the current account, the coefficient of variation of exports, and the ratio of imports to GDP are considered. More exports volatility or a larger demand for imports should be associated with the willingness to hold larger international reserves. In addition, the vulnerability of a country to a crisis can be measured in term of its immediate foreign exchange-denominated debt obligations or, ultimately, by the size of its money supply, measuring the limit on possible asset withdrawal. Also, financially open economies are more exposed to shocks which could explain larger accumulation of reserves. The model also incorporates short-term external debt-to-GDP, M2to-GDP, and FDI net inflows-to-GDP variables to capture potential risks on the capital account.

\footnotetext{
${ }^{4}$ A full list of the countries as well as a description of the variables used in the econometric analysis is provided in Annex III.
} 
Table 4. Determinants of Foreign

Reserves, 1970-2009 1/

\begin{tabular}{|c|c|c|}
\hline & $\begin{array}{l}\text { Fixed } \\
\text { effects }\end{array}$ & $\begin{array}{c}\text { Difference } \\
\text { GMM }^{2 \prime} \\
\end{array}$ \\
\hline \multirow[t]{2}{*}{ IR/GDP(-1) } & & $0.452^{* *}$ \\
\hline & & $(0.198)$ \\
\hline \multirow[t]{2}{*}{ PCGDP } & $0.003^{*}$ & 0.005 \\
\hline & $(0.001)$ & $(0.018)$ \\
\hline \multirow[t]{2}{*}{$\mathrm{PCGDP}^{\wedge} 2$} & $-0.0001^{* * *}$ & -0.0004 \\
\hline & $(0.000)$ & $(0.0007)$ \\
\hline \multirow[t]{2}{*}{ IMPORT/GDP } & $0.104^{* * *}$ & 0.194 \\
\hline & $(0.034)$ & $(0.137)$ \\
\hline \multirow[t]{2}{*}{ EXPORTVOL } & $0.119^{* * *}$ & $0.150^{* * *}$ \\
\hline & $(0.038)$ & $(0.040)$ \\
\hline \multirow[t]{2}{*}{ OPORTUNITY COST } & $-0.009^{* * *}$ & -0.003 \\
\hline & $(0.002)$ & $(0.003)$ \\
\hline \multirow[t]{2}{*}{ EXR.FLEX } & $-0.003^{*}$ & $-0.495^{\star}$ \\
\hline & $(0.021)$ & $(0.296)$ \\
\hline \multirow[t]{2}{*}{ FDI/GDP } & $0.371^{* *}$ & $0.391^{*}$ \\
\hline & $(0.172)$ & $(0.242)$ \\
\hline \multirow[t]{2}{*}{ M2/GDP } & $0.128^{* * *}$ & $0.241^{* *}$ \\
\hline & $(0.028)$ & $(0.122)$ \\
\hline \multirow[t]{2}{*}{ ST.DEBT/GDP } & -0.045 & -0.392 \\
\hline & $(0.073)$ & $(0.384)$ \\
\hline \multirow[t]{2}{*}{ REGIONAL IMITATION } & $0.110^{* * *}$ & 0.001 \\
\hline & $(0.021)$ & $(0.028)$ \\
\hline \multirow[t]{2}{*}{ MCDOILEXPORTERS } & $0.049^{* * *}$ & \\
\hline & $(0.015)$ & \\
\hline \multicolumn{3}{|l|}{ OILEXPORTERS } \\
\hline \multicolumn{3}{|l|}{ MAGHREB } \\
\hline \multirow{2}{*}{$\begin{array}{l}\text { Over-identification } \\
\text { ( } p \text { value) }\end{array}$} & & Sargan: \\
\hline & & 0.619 \\
\hline No. of observations & 585 & 564 \\
\hline No. of instruments & & 17 \\
\hline No. of countries & 17 & 17 \\
\hline
\end{tabular}

$1 /$ Dependent variable is ratio of foreign reserves to GDP. Robust standard errors in parenthesis; ${ }^{* * *}\left({ }^{* *},{ }^{*}\right)$ indicate significance at $1(5,10)$ percent.

2/ Two step, instruments based on second lag of IR/GDP, and first lag of PCGDP, PCGDP^2, EXPORTVOL, EXR.FLEX, M2/GDP, and ST.DEBT/GDP. 
15. Other variables considered include: (i) a measure of the exchange rate flexibility, assuming that more flexibility would be associated with less need to hold reserves; (ii) the opportunity cost of holding these assets, as measured by the interest rate on 10-year U.S. treasuries; (iii) a quadratic relationship between reserves and the level of development, as measured by the per capita GDP and its quadratic term, assuming that middle-income countries are more prone to financial crisis than high- or low-income countries and are, therefore, more interested in using reserves as a precautionary buffer; ${ }^{5}$ (iv) the existence of regional imitation (peer effects), as a country might be more vulnerable to capital outflows if it is considered not to have an inadequate level of reserves compared to countries with similar economic characteristics. Finally, a set of dummy variables to account for hydrocarbon-exporting countries, commodity-exporting countries, and the Maghreb region is included in the estimations.

Figure 3. Algeria's International Reserves, Actual Versus Fitted Values (In Percent of GDP)

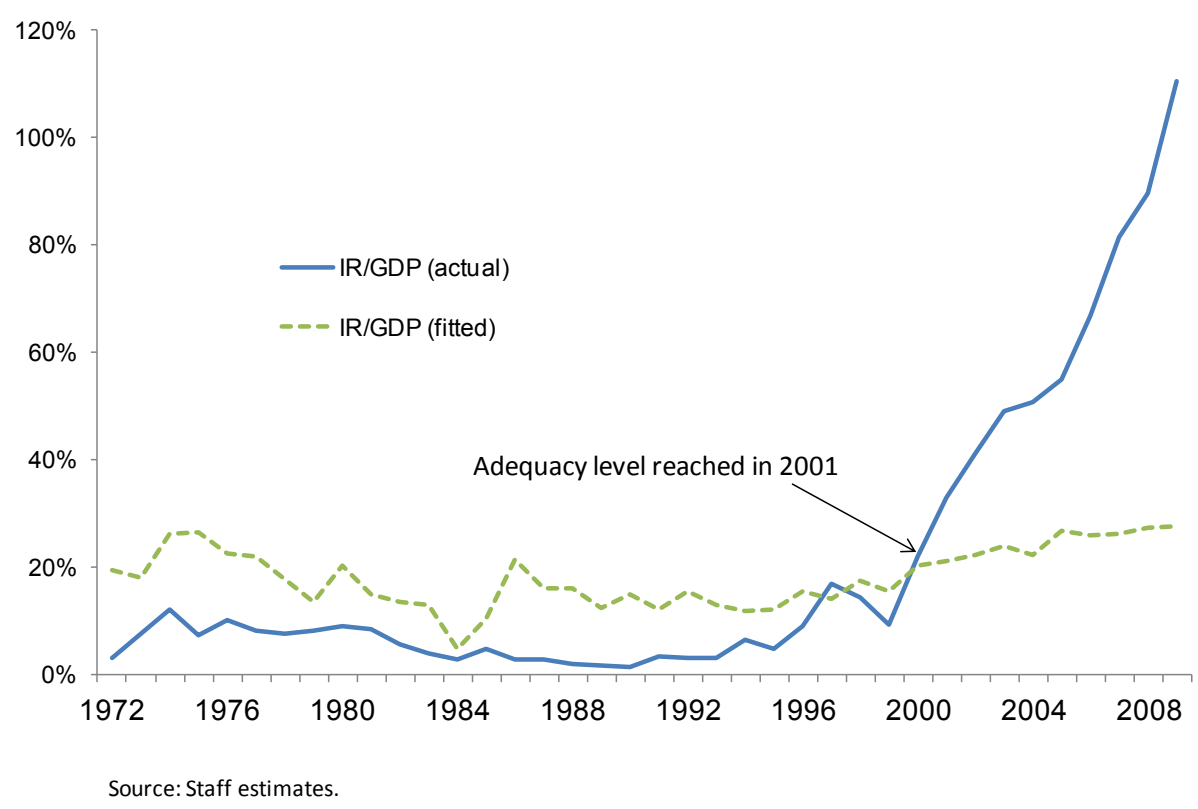

16. Table 4 reports the results for the estimated equation. The fixed-effects model (column 1), provides important insights on the main variables that potentially affect reserve accumulation. As expected, the model finds a positive and significant relationship between reserve accumulation and the volatility of exports, and the level of imports to GDP. In addition, broad money and FDI flows are also found positive and significant, confirming the motivation for reserves accumulation based on capital account risk. The results also show that floating exchange rate regimes are associated with less reserve accumulation. The estimated coefficients for the quadratic relationship with the level of country development,

\footnotetext{
${ }^{5}$ For an explanation, see Bastourre et al., 2009.
} 
the opportunity cost, and the regional imitation determinants are found significant and present the correct signs. Finally, MCD oil exporters present a reserve-to-GDP ratio about 4.9 percentage points higher on average - after controlling for the standard demand driversas shown by the significant positive coefficient of the dummy for this group of countries. ${ }^{6}$

17. A comparison of actual versus fitted values for the level of international reserves as percent of GDP shows that reserve accumulation was below the minimum required by economic fundamentals until 2002. However, the model cannot explain the massive accumulation of reserves in Algeria since the early 2000s.

18. It can be argued that the use of a fixed-effects model may create some specification problems. First, some of the explanatory variables may be endogenous, causing the regressors to be correlated with the error term. Second, time-invariant country characteristics (fixed effects), may be correlated with the explanatory variables. Third, the presence of the lagged dependent variables gives rise to autocorrelation. To account for these potential problems we have estimated a second model (column 2) using the Arellano-Bond Difference GMM estimator. With this model specification, the volatility of exports and broad money still present positive and significant coefficients, confirming the motivation for reserve accumulation based on current account and capital account risk accumulation. More exchange rate flexibility is also negatively associated with the need for reserve accumulation.

19. For robustness purposes, a different model specification is considered in which the degree of openness of the economy, calculated as the sum of imports and exports to GDP, is incorporated (see Obstfeld et al., 2008). As anticipated in the literature, the degree of openness of the economy is significant and positively associated with reserve accumulation, both under the fixed effects and the difference GMM model. All estimated coefficients and the different model specifications can be found in Annex III.

\footnotetext{
${ }^{6}$ Oil exporters (MCD oil exporters plus Angola, Nigeria, and Venezuela) present a reserve-to-GDP ratio about 7 percent higher. For Maghreb countries, in contrast, the reserve-to-GDP ratio is 4.2 percent lower, a fall which is due to the inclusion of two oil importers: Morocco and Tunisia (See Annex III).
} 


\section{Adjusting Reserves to the Algerian Policy Framework: the Permanent Income Approach}

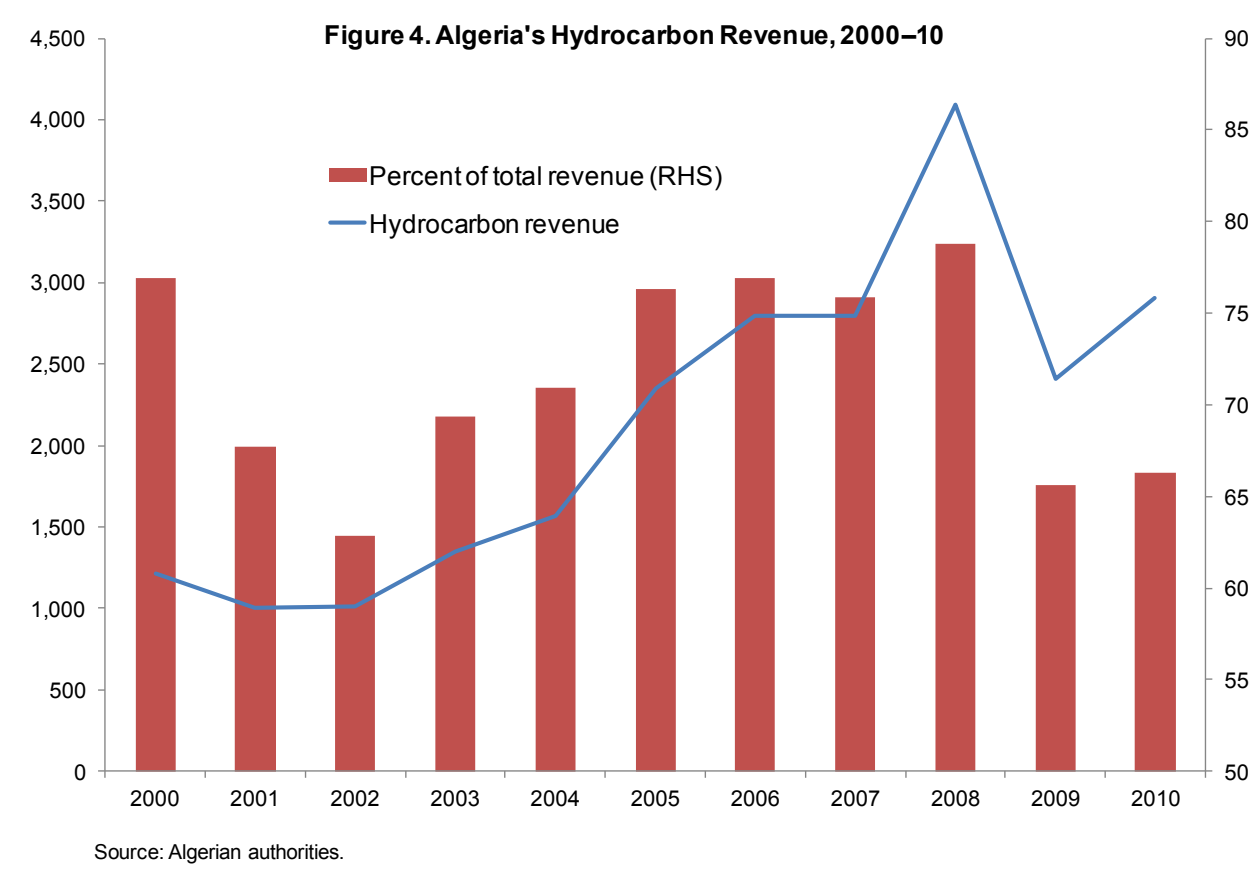

20. The next assessment of the reserve adequacy considers the inter-temporal use of Algeria's large hydrocarbon resource, and rests on the assumption that oil and natural gas reserves are nonrenewable resources with size and potential for exploitation subject to uncertainty. These natural resources are a source of large fiscal revenues (Figure 4) across generations, and fiscal policy should spread the benefits across generations, allowing future generations to enjoy part of the hydrocarbon wealth after their source is depleted. Government should then save part of the hydrocarbon revenues to sustain spending levels over the very long-term (i.e. 30 to 40 years). One possibility for ensuring fiscal sustainability, considering this budget constraint, would be for the government not to spend from its current hydrocarbon revenues but out of what is considered its permanent income. ${ }^{78}$ The next paragraphs make an analytical presentation of the permanent income framework (PIF).

21. The PIF lies on the accounting identity that links a country's current account balance (CA) to the excess of domestic saving (S) over domestic investment (I), considering both the public and private sectors: ${ }^{9}$

\footnotetext{
${ }^{7}$ Floerkemeier (2004) made a full application of the permanent income approach to Algeria. Aussaoui (2001) and World Bank (2003) do earlier applications of this framework. Loko (2008) uses the same analysis to estimate Algeria's equilibrium real exchange rate.

${ }^{8}$ See Floerkemeier, (2004) page 20 for a country list of applications of the permanent income framework.

${ }^{9}$ This analytical framework is based on Loko (2008).
} 


$$
\mathrm{CA}=(\mathrm{Sg}-\mathrm{Ig})+\left(\mathrm{Sp}-\mathrm{I}_{\mathrm{p}}\right)
$$

where $\mathrm{g}$ denotes the government and $\mathrm{p}$ denotes the nongovernment sector.

22. Within the public sector, the gap between savings and investment $\left(\mathrm{S}_{g}-\mathrm{Ig}\right)$ is the fiscal balance. Moreover, the fiscal balance is defined as the difference between hydrocarbon revenue (HR) and the nonhydrocarbon fiscal balance (NHFB) - the difference between nonhydrocarbon revenue and total expenditure. As a result, we can rewrite the CA as follows:

$$
\mathrm{CA}=\mathrm{HR}+\mathrm{NHFB}+\left(\mathrm{S}_{\mathrm{p}}-\mathrm{I}_{\mathrm{p}}\right)
$$

23. This analytical framework assumes a current account norm that is consistent with fiscal sustainability as defined by applying the permanent income framework (PIF). The hypothesis is forward-looking, as it assumes that government should save part of its current income for future generations. Under the PIF, hydrocarbon revenue is split between the part that should be saved, SPIF, and the part than can be consumed, RPIF (which is equal to the nonhydrocarbon fiscal balance).

$$
\begin{aligned}
& \mathrm{HR}=\mathrm{RPIF}+\mathrm{SPIF}_{\mathrm{PIF}} \\
& \mathrm{RPIF}+\mathrm{NHFB}=0
\end{aligned}
$$

24. Combining equations 2,3 , and 4 , the current account norm $\left(\mathrm{CA}_{n}\right)$ consistent with the PIF sustainable fiscal balance is the sum of the implied saving under the PIF and the savinginvestment balance of the nongovernment sector.

$$
\mathrm{CAn}_{n}=\mathrm{SPIF}+(\mathrm{Sp}-\mathrm{Ip})
$$

25. Based on this analytical framework, it is possible to compute the current account norm under the PIF using two different arbitrary rules: (a) keeping constant total real government wealth (rule 1); and (b) total real hydrocarbon wealth constant in per capita terms (rule 2). The second rule implies a larger saving (CA norm) than the first one because it takes into account population growth.

26. Table 5 presents the results of the application of the PIF to reserve adequacy in Algeria. Column 1 shows the actual reserve accumulation in US\$ billions; column 2 shows the projection of the current account norm that is the savings required each year to respect the permanent income per capita rule up to $2050,{ }^{10}$ and column 3 displays the accumulated net

\footnotetext{
${ }^{10}$ The PIF requires assumptions about future hydrocarbon production and exports, as well as interest/discount rates. An additional underlying assumption is that the capital account balance compensates the nongovernmental savings-investment gap $(\mathrm{Sp}-\mathrm{Ip}=0)$.
} 
savings. Columns 4, 5, 6, and 7 are the different components of the WK reserve adequacy composite (see Section II). Column 8 shows the required capital expenditure imports for large government and investment plans in the hydrocarbon sector. The last two columns present the estimated net excess reserves considering only the WK components (column 9) or considering required capital expenditure imports instead of the 3-month import coverage ratio (column 10).

27. Based on this framework, the accumulation of reserves has been broadly consistent with the PIF norm, albeit somewhat larger in the last few years. The PIF norm is substantially higher than in adequacy assessment based on traditional methods. This methodology also requires greater reserve accumulation than the minimum level required by fundamentals (as predicted in the empirical analysis in part III) because it implies an intergenerational motivation for reserve accumulation not considered there. Moreover, the effects of the precautionary motive to face uncertainty over commodity prices which usually requires greater reserve accumulation has not been taken into account (Bems and Carvalho Filho, 2009 and Takabe and York, 2011) and would probably require a higher level of reserve accumulation.

Table 5. Algeria's Excess Reserves Under the Permanent Income Scenario and WK's Composites

\begin{tabular}{|c|c|c|c|c|c|c|c|c|c|c|}
\hline & 1 & 2 & 3 & 4 & 5 & 6 & 7 & 8 & 9 & 10 \\
\hline & $\begin{array}{l}\text { Reserve } \\
\text { accum. }\end{array}$ & $\begin{array}{c}\text { Reserve } \\
\text { accum. } \\
\text { under PIF } \\
\text { norm }\end{array}$ & $\begin{array}{c}\text { Net } \\
\text { savings }\end{array}$ & $\begin{array}{l}\text { Accum. } \\
\text { net } \\
\text { savings } \\
\text { (1) }\end{array}$ & $\begin{array}{c}\text { Short-term } \\
\text { debt } \\
(2)\end{array}$ & $\begin{array}{l}3 \text { months } \\
\text { of imports } \\
\text { coverage } \\
\text { (3) }\end{array}$ & $\begin{array}{c}\mathrm{M} 2^{*} 20^{*} \\
100 \% \text { risk } \\
(4)\end{array}$ & $\begin{array}{c}\text { Required } \\
\text { capital } \\
\text { expenditur } \\
\text { e imports } \\
(5) \\
\end{array}$ & $\begin{array}{c}\text { Net } \\
\text { excess } \\
\text { reserves } \\
A=1-2-3-4\end{array}$ & $\begin{array}{c}\text { Net } \\
\text { excess } \\
\text { reserves } \\
B=1-2-4-5\end{array}$ \\
\hline 2003 & 9.9 & 34.5 & -24.7 & -24.7 & 0.2 & 4.1 & 9.2 & 4.5 & -38.2 & -38.7 \\
\hline 2004 & 10.1 & 32.6 & -22.5 & -47.1 & 0.6 & 5.5 & 10.0 & 4.6 & -63.2 & -62.4 \\
\hline 2005 & 13.1 & 8.9 & 13.1 & -34.1 & 1.8 & 6.2 & 11.1 & 5.5 & -53.1 & -52.4 \\
\hline 2006 & 21.6 & 14.2 & 21.6 & -12.4 & 0.1 & 6.4 & 13.6 & 7.8 & -32.5 & -33.9 \\
\hline 2007 & 32.4 & 17.3 & 32.4 & 20.0 & 0.6 & 8.3 & 17.9 & 14.0 & -6.9 & -12.6 \\
\hline 2008 & 32.9 & 29.6 & 32.9 & 52.9 & 0.3 & 11.9 & 16.8 & 23.2 & 23.9 & 12.6 \\
\hline 2009 & 5.8 & 5.0 & 5.8 & 58.7 & 0.3 & 11.9 & 19.2 & 25.3 & 27.3 & 14.0 \\
\hline 2010 & 13.6 & 11.3 & 13.6 & 72.3 & 0.3 & 12.6 & 21.1 & 23.2 & 38.2 & 27.7 \\
\hline
\end{tabular}

28. Despite having been broadly in line with the PIF optimal level of reserves in the recent years, the PIF shows that any potential excess in the level of reserves needs to be consistent with the savings norm to keep per capita income (or wealth) constant over the medium term. In other words, if excess reserve accumulation resulting from higher-thanexpected oil revenues motivates unsustainable fiscal expansions, the excess reserves will dwindle over the medium term and could affect efforts to maintain a certain level of permanent income per capita constant over the medium term. 
29. Figure 5 shows the annual gross level of reserve accumulation ${ }^{11}$ needed for keeping hydrocarbon wealth per capita constant over the long term, starting in 2003. This PIF norm (blue line) shows that accumulated reserves reach a maximum and then start to decline due to the progressive exhaustion of reserves over time. The two scenarios (green and red lines) show the actual reserve accumulation for the period 2003-10, and the projected level of reserve accumulation for 2011-43 based on different assumptions for the projected fiscal expansion. The actual accumulation of reserves has been somewhat larger than the PIF norm since 2007, based on actual oil prices for the 2003-10 period.

30. Scenario one is the most conservative with respect to the projected fiscal expansion. It assumes WEO medium-term projections for the period 2011-16. It further assumes a projected fiscal expansion that would be perfectly consistent with the long-term reserve accumulation level implied by the PIF norm starting in 2017. In this scenario, the excessive accumulation of reserves that originated in the period 2005-10 is not reversed. The effective accumulation of reserves remains slightly above the PIF norm during the full sample period.

31. A first conclusion from the application of the PIF to the case of Algeria is that for the period between 2005 and 2010, there appears to have been an excess level of reserve accumulation that would persist until 2016 based on the current WEO projections. This larger reserve accumulation (ex-post) may be explained by a level of fiscal expansion that was based on expected oil prices well below the effective ones during the period. As a matter of fact, an increase in the oil price projection over the sample period would move the PIF norm upwards, eliminating the excess reserve accumulation. This appears to be the case during the period 2005-2010, in which actual oil prices were in some years substantially above the WEO oil prices projected the previous year, upon which government expenditure plans may have been based.

32. Scenario 2 considers a more expansionary fiscal policy for the period $2013-43$ by assuming that the level of fiscal deficit for the period is kept constant at the 2011 level over the long term. It shows that despite the larger reserve accumulation during the early period (2005-10), reserves start to decline at a faster pace and the permanent income rule is maintained for fewer years than in PIF norm case.

\footnotetext{
${ }^{11}$ For simplicity, the figure is based on the gross annual level of accumulation, which excludes additional reserve accumulation needs due to traditional reserve adequacy ratios (short-term debt, imports, and money aggregates) or Algeria's required imports of capital goods considered in Table 5.
} 
Figure 5. Reserve Accumulation Forecast Under the Permanent Income Framework, 2003-43, in 2003 Constant US\$ Billion

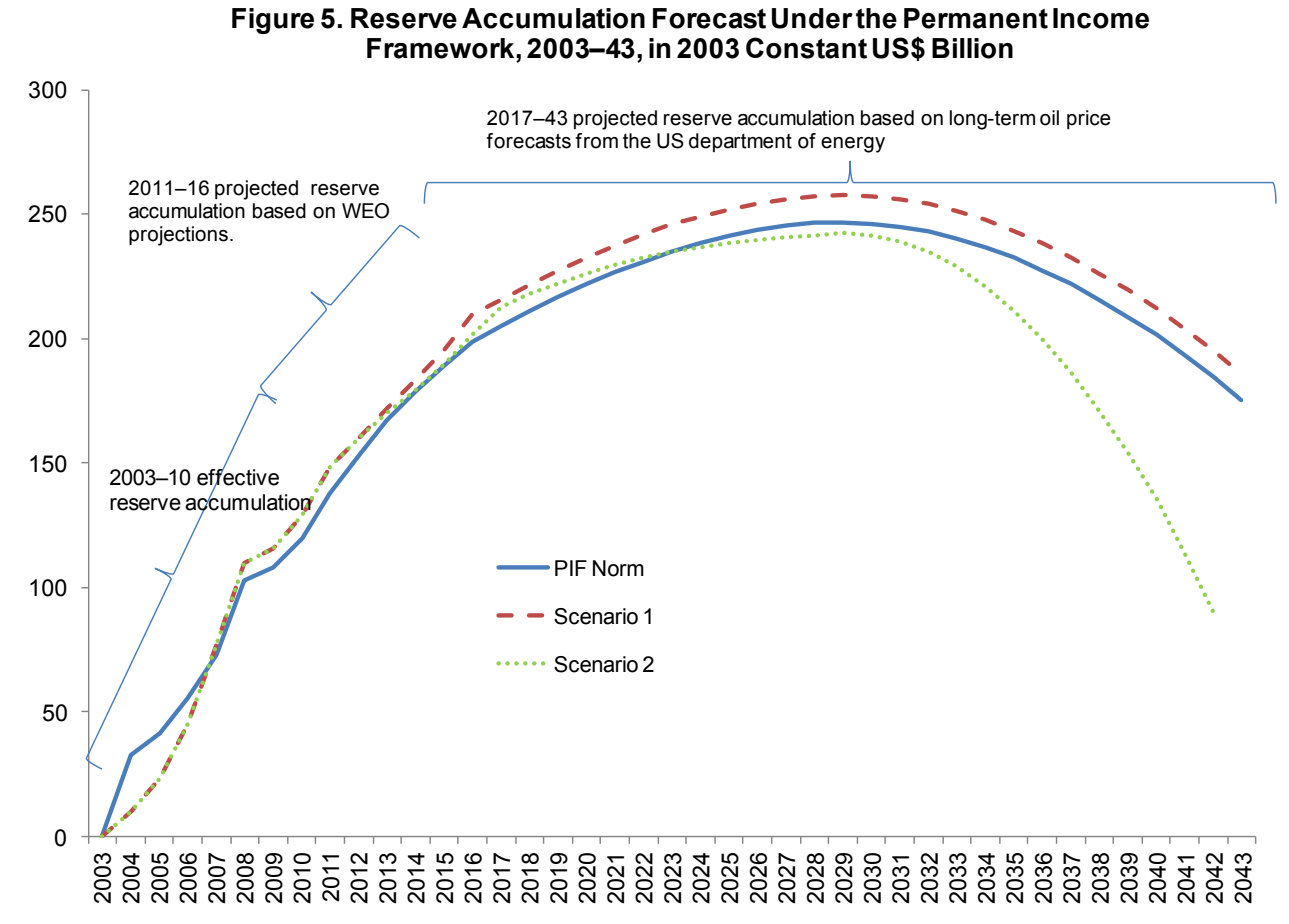

E. Conclusions

33. This paper assesses the level of international reserves adequacy in Algeria using a wide array of benchmarks and alternative methods. This task is more challenging for natural resources exporters like Algeria because these countries have to save part of the export receipts and reserves for the period after the exhaustion of the natural resource. Based on traditional metrics used in the reserve adequacy literature, the current level of reserves seems to exceed traditional benchmarks. However, standard econometric techniques and the application of a permanent income framework show that, although still high, reserve accumulation in Algeria is less excessive than what is implied by traditional analysis. The permanent income framework suggests that the pace of reserve accumulation in Algeria has been somewhat higher than the one implied by the underlying PIF norm only after 2008, thanks to a period of high actual oil prices and generally prudent fiscal policy.

34. The findings of this paper also show that with independence of the reserve adequacy methodology, the current level of reserve accumulation calls for an assessment on how to manage them to ensure that their value is preserved over time. This is particularly important if the authorities consider a permanent income perspective in which part of these assets is preserved for future generations. Algerian authorities have been prudent in their management, placing all reserves in low-risk sovereign debt products while ensuring an acceptable yearly return of around 3 percent. Although this is a considerable achievement, the authorities could consider alternative reserve placement strategies to ensure a greater return of the wealth accumulated for future generations. 
35. More broadly, this study clearly shows that reserve adequacy assessment for commodity exporters in general and oil exporters in particular requires a different analytical framework. Reserve adequacy measures that do not consider the idiosyncrasies of commodity exporters (especially oil and gas) could severely underestimate the real levels of reserve adequacy in these countries. 


\section{REFERENCES}

Aissaoui, A., 2001, Algeria: The Political Economy of Oil and Gas, (Oxford: Oxford University Press).

Bastourre, D., J. Carrera, and J. Ibarlucia, 2009, What is Driving Reserve Accumulation? A Dynamic Panel Data Approach, Review of International Economics 17(4), 861-77

De Beaufort Wijnholds, J. and A. Kapteyn, 2001, Reserve Adequacy in Emerging Market Economies, IMF Working Paper No. 01/143 (Washington: International Monetary Fund)

De Gregorio, J., B. Eichengreen, T. Ito, and C. Wyplosz, 1999, “An Independent and Accountable IMF," Geneva Reports on the World Economy 1 (Geneva/Washington: International Center for Monetary and Banking Studies/Center for Economic Policy Research).

Dehesa M., E. Pineda, and S. Wendell, 2009, "Optimal Reserves in the Eastern Caribbean Currency Union,” IMF Working Paper No. 09/77 (Washington: International Monetary Fund)

Floerkemeier, H., 2004, "Fiscal Management of Hydrocarbon Revenues," in Algeria: Selected Issues (Washington: International Monetary Fund).

International Monetary Fund, 2011, “Assessing Reserve Adequacy,” IMF Policy Papers, February (Washington: International Monetary Fund).

Jeanne, O., and R. Rancière, 2006. "The Optimal Level of International Reserves for Emerging Market Countries: Formulas and Applications," IMF Working Paper No. 06/229 (Washington: International Monetary Fund)

Jeanne, O., 2007, "International Reserves In Emerging Market Countries: Too Much of a Good Thing?" Brookings Papers in Economic Activity, 1: 2007, pp. 1-79.

Loko, B., 2008, "Estimating the Equilibrium Real Exchange Rate in Algeria," in Algeria: Selected Issues (Washington: International Monetary Fund).

The Monitor Company, 2011, "Analyzing the Behavior of Sovereign Wealth Funds, SWFs Assets under Management Table,” (Boston: Monitor Company LLP).

Obstfeld, M., J. Shambaugh, and A. Taylor, 2008, "Financial Stability, the Trilemma, and International Reserves," NBER Working Paper No. 14217 (Cambridge, MA: National Bureau of Economic Research). 
Sensenbrenner, G., 2010, "Des Puissances Financières Internationales de Premier Plan, Questions Internationales" Vol. 46, pp. 31-38

Valencia, F., 2010, "Precautionary Reserves: An Application to Bolivia" IMF Working Paper No. 10/54 (Washington: International Monetary Fund).

World Bank, 2003, "People's Democratic Republic of Algeria: A Medium-Term Macroeconomic Strategy for Algeria-Sustaining Faster Growth with Economic and Social Stability” (Washington: World Bank).

De Carvhalo Filho, I., 2007, "Medium-Term Fiscal Sustainability in Trinidad and Tobago," IMF Country Report No. 07/08 (Washington: International Monetary Fund).

Takizawa, H., 2005, "Fiscal Sustainability and Options for Fiscal Adjustment” IMF Country Report No. 05/234 (Washington: International Monetary Fund).

Thomas, A., J. Kim and A. Aslam, 2008 "Equilibrium Non-Oil Current Account Assessments for Oil Producing Countries," IMF Country Report No. 08/198 (Washington: International Monetary Fund). 


\section{Annex I. Traditional Measures for Reserve AdeQuacy}

\section{Reserves to imports coverage ratio:}

The ratio of reserves to imports measures the number of months that the central bank can continue to pay for all the imports of goods and services if all foreign exchange inflows stop. This benchmark provides a measure of how much time a country can face a negative shock such as sudden change in the terms of trade or an unexpected event such as a natural disaster. It is generally accepted that three months of reserves is the minimum comfort level. In the case of Algeria, the reserves-to-imports ratio has improved dramatically during the past couple of decades. The ratio was well below acceptable levels in the early 1990s, at about 2 months of imports, and started to improve by the end of the decade to reach three years of imports by the end of 2010 .

Table 1. International Reserves to Imports Ratio (In months of imports of goods and services)

\begin{tabular}{lrrrrrr}
\hline & $2000-05$ & 2006 & 2007 & 2008 & 2009 & 2010 \\
\hline MENA oil and gas exporters & & & & & & \\
Algeria & 14.7 & 26.5 & 28.1 & 27.8 & 36.0 & 38.7 \\
Bahrain & 3.2 & 2.0 & 2.6 & 3.1 & 3.7 & 3.2 \\
Iran & 4.6 & 8.9 & 10.1 & 11.7 & 12.8 & 12.5 \\
Kuwait & 6.0 & 4.1 & 4.8 & 5.6 & 6.1 & 9.4 \\
Libya & 21.2 & 29.8 & 34.8 & 37.5 & 41.1 & 38.2 \\
Oman & 4.2 & 3.8 & 3.1 & 4.3 & 6.4 & 6.0 \\
Qatar & 3.2 & 2.5 & 2.4 & 2.8 & 2.6 & 6.2 \\
Saudi Arabia & 4.0 & 16.1 & 18.4 & 20.5 & 31.4 & 25.4 \\
Sudan & 1.0 & 2.2 & 1.8 & 1.3 & 1.8 & 1.0 \\
United Arab Emirates & 3.1 & 2.2 & 2.2 & 4.3 & 1.9 & \\
Yemen & 10.3 & 9.4 & 9.6 & 8.4 & 12.5 & 7.8 \\
MENA oil and gas importers & & & & & & \\
Tunisia & 2.6 & 3.2 & 4.0 & 3.6 & 5.0 & 5.5 \\
Morocco & 7.1 & 7.4 & 7.1 & 6.3 & 7.3 & 6.0 \\
Other oil and gas exporters & & & & & & \\
Angola & 1.1 & 2.4 & 3.9 & 3.1 & 7.5 & 3.7 \\
Nigeria & 5.0 & 10.8 & 11.8 & 12.1 & 13.8 & \\
Venezuela & 7.3 & 7.6 & 6.6 & 5.1 & 7.6 & 5.3 \\
\hline
\end{tabular}

Table IA shows the evolution of the ratio of international reserves to imports in the 2000s for a selected group of MCD oil and gas exporters, MCD oil and gas importers, and other oil and gas exporters from other regions. It shows that Algeria has one of the largest ratios among the selected countries, reflecting the significant improvements in the current account during the second part of the decade due to high hydrocarbon prices. 


\section{Reserves to short-term debt ratio}

The second traditional ratio to assess reserve adequacy is the ratio of reserves to external short-term debt (on a remaining maturity basis), which measures the country's capacity to face short-term international payments in the event of a sudden interruption of international financing. This ratio is considered the most relevant for measuring reserve adequacy in emerging markets, and it is usually considered that it should be around 1, implying that countries should be able to cover repayments of external debt for at least one year. Table IB presents the ratio for a selected group of countries for 2000-09. It shows that Algeria has by far the highest ratio of reserves to external short-term debt, well above other oil and gas exporters.

Table 2. International Reserves to Short-Term Debt Ratio (In percent of short-term debt)

\begin{tabular}{lrrrrr}
\hline & $2000-05$ & 2006 & 2007 & 2008 & 2009 \\
\hline MCD oil and gas exporters & & & & & \\
Algeria & 68.9 & 1113.1 & 175.1 & 550.9 & 573.2 \\
Iran & 4.2 & 6.6 & 8.4 & 11.2 & 27.4 \\
Kuwait & 1.5 & 1.0 & 1.3 & 1.3 & 1.5 \\
Libya & 15.9 & 43.2 & 57.8 & 67.2 & 72.1 \\
Oman & 2.6 & 2.6 & 2.6 & 2.0 & 2.1 \\
Qatar & 2.0 & 0.8 & 0.6 & 0.4 & 0.9 \\
Saudi Arabia & 3.3 & 19.0 & 10.7 & 13.7 & 11.0 \\
United Arab Emirates & 1.5 & 0.7 & 1.2 & 0.7 & 0.8 \\
MCD oil and gas importers & & & & & \\
Morocco & 164.2 & 332.3 & 385.1 & 391.8 & 429.4 \\
Tunisia & 164.2 & 2.0 & 2.0 & 2.0 & 2.5 \\
Other oil and gas exporters & & & & & \\
Nigeria & 171.1 &.. &.. &.. &.. \\
Venezuela & 1.8 & 2.5 & 1.6 & 1.9 & 2.6 \\
\hline
\end{tabular}

\section{Reserves to money aggregates ratios}

The third traditional benchmark focuses on the links between international reserves and the financial sector. The most common ratios compare reserves to monetary aggregates such as reserve money or broad money. These ratios are proxies assessing a central bank's capacity to back its liabilities and credibly defend the exchange rate, especially if pegged or tightly managed. The underlying assumption is that in the event of a financial crisis and a loss of confidence in the domestic financial system, residents will attempt to convert local currency into foreign exchange and fly capital out of the country. Table IC presents the ratio of reserves to broad money (M2) and shows that Algeria has the third largest ratio in the sample. 
Table 3. Comparison of Reserves to M2 Ratio (In percent of M2)

\begin{tabular}{lrrrrrr}
\hline & $2000-05$ & 2006 & 2007 & 2008 & 2009 & 2010 \\
\hline MCD oil and gas exporters & & & & & & \\
Algeria & 71.4 & 116.9 & 126.5 & 142.0 & 132.9 & 147.6 \\
Bahrain, Kingdom of & 24.8 & 25.1 & 27.2 & 21.2 & 19.1 & $\ldots$ \\
Iran & 28.0 & 40.2 & 43.2 & 36.8 & 34.8 & $\ldots$ \\
Kuwait & 25.2 & 22.9 & 24.9 & 21.0 & 23.1 & 23.9 \\
Libya & 178.8 & 423.2 & 385.9 & 314.9 & 300.0 & 256.4 \\
Oman & 43.3 & 43.2 & 59.8 & 59.1 & 57.3 & 57.0 \\
Qatar & 17.2 & 17.8 & 22.3 & 19.1 & 33.4 & 42.7 \\
Saudi Arabia & 34.6 & 128.1 & 144.9 & 178.4 & 152.4 & 154.2 \\
Sudan & 18.6 & 20.2 & 14.1 & 12.8 & 9.1 & $\ldots$ \\
United Arab Emirates & 31.3 & 25.4 & 50.1 & 16.2 & 17.8 & 20.0 \\
Yemen & 106.0 & 104.8 & 93.0 & 86.3 & 68.6 & 56.8 \\
MCD oil and gas importers & & & & & & \\
Morocco & 30.1 & 32.9 & 31.3 & 24.5 & 25.0 & 21.6 \\
Tunisia & 19.4 & 34.0 & 33.7 & 31.9 & 39.6 & 31.6 \\
Other oil and gas exporters & & & & & & \\
Angola & 43.9 & 100.4 & 83.5 & 67.4 & 50.8 & 57.5 \\
Nigeria & 88.6 & 135.1 & 111.2 & 68.5 & 62.3 & 45.3 \\
Venezuela & 66.6 & 47.1 & 31.1 & 34.1 & 19.4 & $\ldots$ \\
\hline & & & & & &
\end{tabular}




\section{ANNEX II. ESTIMATION OF RESERVE ADEQUACY FOR OIL EXPORTERS WITH SOVEREIGN WEALTH FUNDS}

Sovereign Wealth Funds in MCD Oil exporters: Bahrain, Kuwait, Qatar, and United Arab Emirates.

\begin{tabular}{|l|l|c|c|c|}
\hline \multicolumn{1}{|c|}{ Country } & \multicolumn{1}{|c|}{ Name } & $\begin{array}{c}\text { Total Assets } \\
\text { in USD } \\
\text { billion }\end{array}$ & $\begin{array}{c}\text { Distribution of } \\
\text { portfolio of assets }\end{array}$ & $\begin{array}{c}\text { Liquid funds } \\
\text { equivalent to } \\
\text { reserves in US\$ } \\
\text { billion }\end{array}$ \\
\hline Bahrain & $\begin{array}{l}\text { Bahrain Mumtalakat } \\
\text { Holding Company BSC }\end{array}$ & 13.0 & $\begin{array}{c}\text { No information } \\
\text { disclosed }\end{array}$ & $7-10$ \\
\hline Kuwait & $\begin{array}{l}\text { Kuwait Investment } \\
\text { Authority }\end{array}$ & 295.0 & $66 \%-80$ & $195-237$ \\
\hline Qatar & $\begin{array}{l}\text { Qatar Investment } \\
\text { Authority }\end{array}$ & 70.0 & $\begin{array}{c}\text { No information } \\
\text { disclosed }\end{array}$ & $39-54$ \\
\hline Oman & $\begin{array}{l}\text { State General Reserve } \\
\text { Fund }\end{array}$ & 8.2 & $\begin{array}{c}\text { No information } \\
\text { disclosed }\end{array}$ & $5-6$ \\
\hline $\begin{array}{l}\text { United Arab } \\
\text { Emirates }\end{array}$ & $\begin{array}{l}\text { Abu Dhabi Investment } \\
\text { Authority }\end{array}$ & 439.3 & $45 \%-75 \%$ & $154-257$ \\
\hline
\end{tabular}

Source: Staff Estimates based on The Monitor Group, LLP, (2010 and 2011), Sensenbrenner (2010 and IMF 2008).

\section{Reserve adequacy ratio considering available resources in Sovereign Wealth Funds:}

We assume that these countries can convert their liquid and quasi-liquid assets (cash, listed shares and bonds) into cash without substantial investment loss. Moreover, for Qatar and Bahrain we consider the same ratios that that of the average of the minimum and maximum shares in liquid assets for Kuwait and the United Arab Emirates.

\begin{tabular}{|l|c|c|c|c|c|c|}
\hline Country & $\begin{array}{c}\text { Reserves to } \\
\text { imports ratio } \\
\text { based on } \\
\text { published } \\
\text { reserves data }\end{array}$ & $\begin{array}{c}\text { Adjusted } \\
\text { ratio }\end{array}$ & $\begin{array}{c}\text { Reserves to short- } \\
\text { term debt to ratio } \\
\text { based on } \\
\text { published reserves } \\
\text { data }\end{array}$ & $\begin{array}{c}\text { Adjusted } \\
\text { ratio }\end{array}$ & $\begin{array}{c}\text { Reserves to } \\
\text { monetary } \\
\text { aggregates ratio } \\
\text { with published } \\
\text { reserves data }\end{array}$ & $\begin{array}{c}\text { Adjusted } \\
\text { ratio }\end{array}$ \\
\hline Bahrain & 3.2 & $6-8$ & N.A. & N.A. & 16.7 & $53-67$ \\
\hline Kuwait & 9.4 & $100-119$ & 1.4 & $17-20$ & 23.9 & $244-291$ \\
\hline Oman & 6.0 & $9-10$ & 1.9 & 3 & 57.0 & $77-85$ \\
\hline Qatar & 6.2 & $10-12$ & 1.1 & 3 & 23.9 & $97-118$ \\
\hline $\begin{array}{l}\text { United Arab } \\
\text { Emirates }\end{array}$ & 2.2 & $14-21$ & $0.8(2009)$ & $5-8$ & 20 & $98-146$ \\
\hline
\end{tabular}

Source: Staff estimates. 


\section{ANNEX III. DETERMINANTS OF FOREIGN RESERVES}

\section{A. Country Sample}

MCD Oil exporters: Algeria, Bahrain, Iran, Kuwait, Libya, Oman, Qatar, Saudi Arabia, Sudan, United Arab Emirates, and Yemen

Other Oil exporters: Angola, Nigeria, Venezuela

Oil importers: Chile, Morocco, Tunisia

\section{B. Construction of the Variables and Data Sources}

Data for all variables was obtained either from the International Financial Statistics (IFS) or the World Economic Outlook, including data on international reserves, GDP at current prices, total population, exports on goods, imports of goods, broad money (M2), net direct investment, and short term external debt. The dependent variable is the ratio of international reserves to GDP. For international reserves we have considered the series that excludes gold from the International Financial Statistics (IFS). All variables are expressed in US Dollars. We have constructed, additionally, the following indicators:

- Trade openness: sum of exports and imports of goods expressed in percentage of GDP.

- Volatility of Exports: The volatility of exports in year $t$ was constructed taking the standard deviation of exports for the years: $t, t-1, t-2, t-3, t-4$, to the respective sample average, via a rolling window calculation.

- Regional imitation: this variable calculates the ratio between the number of countries in a region that increased their total reserves during the previous year and the total number of countries making up the corresponding geographical region. We consider three regions: MCD oil exporters, MCD oil importers (Morocco, Tunisia), and rest.

- Dummy variables: these include one for the group of MCD oil exporters, one for all oil exporting countries (MCD + Angola, Nigeria, and Venezuela), and another for the Maghreb region (Algeria, Morocco, and Tunisia) 


\section{Alternative Model Specifications}

Table 1. Determinants of Foreign Reserves in Oil Exporting Countries, MCD Oil Exporting Countries, and the Maghreb Region, $1970-09^{1 /}$

\begin{tabular}{|c|c|c|c|c|}
\hline & (1) & (2) & (3) & (4) \\
\hline & $\begin{array}{l}\text { Fixed } \\
\text { effects }\end{array}$ & $\begin{array}{l}\text { Fixed } \\
\text { effects }\end{array}$ & $\begin{array}{l}\text { Fixed } \\
\text { effects }\end{array}$ & $\begin{array}{c}\text { Difference } \\
\text { GMM }^{2 /}\end{array}$ \\
\hline IR/GDP(-1) & & & & $\begin{array}{l}0.452^{* *} \\
(0.198)\end{array}$ \\
\hline PCGDP & $\begin{array}{l}0.003^{*} \\
(0.001)\end{array}$ & $\begin{array}{l}0.002 \\
(0.001)\end{array}$ & $\begin{array}{l}0.003^{*} \\
(0.001)\end{array}$ & $\begin{array}{c}0.005 \\
(0.018)\end{array}$ \\
\hline PCGDP^2 & $\begin{array}{c}-0.0001^{* * *} \\
(0.000)\end{array}$ & $\begin{array}{l}-0.000^{* * *} \\
(0.000)\end{array}$ & $\begin{array}{l}-0.000^{* * *} \\
(0.000)\end{array}$ & $\begin{array}{l}-0.0004 \\
(0.0007)\end{array}$ \\
\hline IMPORT/GDP & $\begin{array}{c}0.104^{* * *} \\
(0.034)\end{array}$ & $\begin{array}{l}0.105^{* * *} \\
(0.034)\end{array}$ & $\begin{array}{l}0.118^{* * *} \\
(0.034)\end{array}$ & $\begin{array}{c}0.194 \\
(0.137)\end{array}$ \\
\hline EXPORTVOL & $\begin{array}{l}0.119^{* * *} \\
(0.038)\end{array}$ & $\begin{array}{l}0.093^{* *} \\
(0.038)\end{array}$ & $\begin{array}{l}0.126^{* * *} \\
(0.038)\end{array}$ & $\begin{array}{l}0.150^{* * *} \\
(0.040)\end{array}$ \\
\hline OPORTUNITY COST & $\begin{array}{l}-0.009^{* * *} \\
(0.002)\end{array}$ & $\begin{array}{l}-0.010^{* * *} \\
(0.001)\end{array}$ & $\begin{array}{l}-0.007^{* * *} \\
(0.002)\end{array}$ & $\begin{array}{l}-0.003 \\
(0.003)\end{array}$ \\
\hline EXR.FLEX & $\begin{array}{l}-0.003^{*} \\
(0.021)\end{array}$ & $\begin{array}{l}-0.051^{* *} \\
(0.021)\end{array}$ & $\begin{array}{l}-0.040^{*} \\
(0.022)\end{array}$ & $\begin{array}{l}-0.495^{*} \\
(0.296)\end{array}$ \\
\hline FDI/GDP & $\begin{array}{l}0.371^{* *} \\
(0.172)\end{array}$ & $\begin{array}{l}0.285^{*} \\
(0.169)\end{array}$ & $\begin{array}{l}0.287^{*} \\
(0.171)\end{array}$ & $\begin{array}{l}0.391^{*} \\
(0.242)\end{array}$ \\
\hline M2/GDP & $\begin{array}{l}0.128^{* * *} \\
(0.028)\end{array}$ & $\begin{array}{l}0.141^{* * *} \\
(0.027)\end{array}$ & $\begin{array}{l}0.170^{* * *} \\
(0.031)\end{array}$ & $\begin{array}{l}0.241^{* *} \\
(0.122)\end{array}$ \\
\hline ST.DEBT/GDP & $\begin{array}{l}-0.045 \\
(0.073)\end{array}$ & $\begin{array}{l}-0.096 \\
(0.072)\end{array}$ & $\begin{array}{l}-0.112 \\
(0.074)\end{array}$ & $\begin{array}{l}-0.392 \\
(0.384)\end{array}$ \\
\hline REGIONAL IMITATION & $\begin{array}{l}0.110^{* * *} \\
(0.021)\end{array}$ & $\begin{array}{l}0.099^{* * *} \\
(0.021)\end{array}$ & $\begin{array}{l}0.118^{* * *} \\
(0.021)\end{array}$ & $\begin{array}{c}0.001 \\
(0.028)\end{array}$ \\
\hline MCDOILEXPORTERS & $\begin{array}{l}0.049^{* * *} \\
(0.015)\end{array}$ & & & \\
\hline OILEXPORTERS & & $\begin{array}{l}0.070^{* * *} \\
(0.016)\end{array}$ & & \\
\hline MAGHREB & & & $\begin{array}{l}-0.042^{* *} \\
(0.019)\end{array}$ & \\
\hline $\begin{array}{l}\text { Over-identification } \\
\text { ( } p \text { value })\end{array}$ & & & & $\begin{array}{l}\text { Sargan: } \\
0.619\end{array}$ \\
\hline No. of observations & 585 & 585 & 585 & 564 \\
\hline No. of instruments & & & & 17 \\
\hline No. of countries & 17 & 17 & 17 & 17 \\
\hline
\end{tabular}

$1 /$ Dependent variable is ratio of foreign reserves to GDP. Robust standard errors in parenthes is; ${ }^{* * *}\left({ }^{* *},{ }^{*}\right)$ indicate significance at $1(5,10)$ percent.

2/ Two step, instruments based on second lag of IR/GDP, and first lag of PCGDP, PCGDP^2, EXPORTVOL, EXR.FLEX, M2/GDP, and ST.DEBT/GDP. 
Table 2. Determinants of Foreign Reserves in Oil Exporting Countries, MCD Oil Exporting Countries, and the Maghreb Region, Alternative Model Specification, 1970-2009 ${ }^{1 /}$

\begin{tabular}{|c|c|c|c|c|}
\hline & (1) & (2) & (3) & (4) \\
\hline & $\begin{array}{l}\text { Fixed } \\
\text { effects }\end{array}$ & $\begin{array}{l}\text { Fixed } \\
\text { effects }\end{array}$ & $\begin{array}{l}\text { Fixed } \\
\text { effects }\end{array}$ & $\begin{array}{c}\text { Difference } \\
\mathrm{GMM}^{2 /}\end{array}$ \\
\hline \multirow[t]{2}{*}{ IR/GDP(-1) } & & & & $0.667^{* * *}$ \\
\hline & & & & $(0.103)$ \\
\hline \multirow[t]{2}{*}{ OPENNESS } & $0.093^{* * *}$ & $0.087^{* * *}$ & $0.098^{* * *}$ & $0.254^{* * *}$ \\
\hline & $(0.019)$ & $(0.021)$ & $(0.026)$ & $(0.059)$ \\
\hline \multirow[t]{2}{*}{ EXPORTVOL } & 0.073 & 0.053 & 0.076 & 0.005 \\
\hline & $(0.058)$ & $(0.05)$ & $(0.060)$ & $(0.057)$ \\
\hline \multirow[t]{2}{*}{ OPORTUNITY COST } & $-0.008^{*}$ & $-0.009^{* *}$ & $-0.007^{*}$ & $-0.003^{*}$ \\
\hline & $(0.004)$ & $(0.004)$ & $(0.004)$ & $(0.001)$ \\
\hline \multirow[t]{2}{*}{ EXR.FLEX } & -0.033 & $-0.046^{*}$ & -0.039 & -0.283 \\
\hline & $(0.024)$ & $(0.027)$ & $(0.025)$ & $(0.223)$ \\
\hline \multirow[t]{2}{*}{ FDI/GDP } & 0.235 & 0.186 & 0.174 & 0.636 \\
\hline & $(0.252)$ & $(0.244)$ & $(0.244)$ & $(0.428)$ \\
\hline \multirow[t]{2}{*}{ M2/GDP } & $0.137^{* * *}$ & $0.146^{* * *}$ & 0.171 & $0.408^{* * *}$ \\
\hline & $(0.042)$ & $(0.035)$ & $(0.037)$ & $(0.069)$ \\
\hline \multirow[t]{2}{*}{ ST.DEBT/GDP } & -0.119 & -0.156 & -0.167 & $-0.295^{\star}$ \\
\hline & $(0.088)$ & $(0.096)$ & $(0.105)$ & $(0.173)$ \\
\hline \multirow[t]{2}{*}{ REGIONAL IMITATION } & $0.093^{* *}$ & $0.086^{* *}$ & $0.100^{* * *}$ & 0.009 \\
\hline & $(0.038)$ & $(0.036)$ & $(0.037)$ & $(0.023)$ \\
\hline \multirow[t]{2}{*}{ MCDOILEXPORTERS } & 0.035 & & & \\
\hline & $(0.033)$ & & & \\
\hline \multirow[t]{2}{*}{ OILEXPORTERS } & & $0.056^{* *}$ & & \\
\hline & & $(0.028)$ & & \\
\hline \multirow[t]{2}{*}{ MAGHREB } & & & -0.034 & \\
\hline & & & $(0.034)$ & \\
\hline
\end{tabular}

Over-identification

Sargan:

( $p$ value)

0.349

No. of observations

585

585

$585 \quad 564$

No. of instruments

17

No. of countries

17

17

$17 \quad 17$

$1 /$ Dependent variable is ratio of foreign reserves to GDP. Robust standard errors in parenthesis; ${ }^{* * *}\left({ }^{* *},{ }^{*}\right)$ indicate significance at 1 $(5,10)$ percent.

2/ Two step, instruments based on second lag of IR/GDP, and first lag of OPENNESS, EXPORTVOL, EXR.FLEX, M2/GDP, and ST.DEBT/GDP. 